\title{
THE FALL AND RISE OF SPECIALIZED FEDERAL CONSTITUTIONAL COURTS
}

\author{
Michael E. Solimine*
}

\begin{abstract}
Most constitutional challenges in federal court to federal statutes are litigated in the familiar pattern of a decision by a single U.S. District Judge, followed by an appeal to a three-judge panel of one of the U.S. Court of Appeals, followed by the filing of a writ of certiorari in the U.S. Supreme Court, which has discretion to grant or deny the writ. Sometimes, however, Congress requires a separate path for constitutional challenges to particular federal statutes, with the frequent challenges to provisions of the Bipartisan Campaign Reform Act, such as in Citizens United v. FEC (2010), being a notable example. These provisions often provide for the convening of a threejudge district court, usually in the District of Columbia, followed by an ostensibly mandatory appeal to the Supreme Court. They often also permit members of Congress to bring or intervene in such actions, and mandate that the federal courts decide the cases in an expeditious manner. All of these characteristics are absent from the typical challenge to federal statutes.
\end{abstract}

These atypical jurisdictional provisions in effect establish specialized if ad hoc federal courts to rule on constitutional issues. The causes and consequences of specialized federal constitutional courts are an understudied phenomenon in the scholarly literature, a gap filled by this article. The Article first summarizes the history of the three-judge district court, founded to consider all constitutional challenges to federal statutes, from its establishment in 1937 to its repeal in 1976. It next documents the instances when Congress has subsequently created such courts on a statutespecific basis, and addresses the rationales advanced in the legislative history, namely, uncertaint over a statute's constitutionality, and the asserted need to promptly resolve that issue. The Article then subjects the partial revival of such courts to critical examination. It argues that a complex and sometimes inconsistent set of reasons, including but not limited to Congressional abdication of constitutional deliberation to the judicial branch, explains the ad hoc adoption of these statutes. The Article argues that other provisions of these laws, such as mandating venue in the District of Columbia or expeditious treatment, are unnecessary. Finally, it contends that cases litigated before these courts have a possibly deleterious impact on the quality of decisions in the Supreme Court. The Article concludes that Congress should not pass these statutes and rather permit all constitutional litigation to proceed in a uniform manner.

* Donald P. Klekamp Professor of Law, University of Cincinnati College of Law. For their helpful comments on an earlier draft, thanks to Tim Armstrong, Aaron Bruhl, Chris Bryant, Jacob Cogan, Neal Devins, Josh Douglas, Rick Hasen, Rich Saphire, Sandra Sperino, and to the participants in faculty workshops at the University of Cincinnati College of Law and the University of Dayton School of Law. Thanks also to Matt Dearden for his excellent research assistance, and the Shott Fund for financial support. (c) 2014 by Michael E. Solimine 
II. The FALl of SPECialized Federal Constitutional

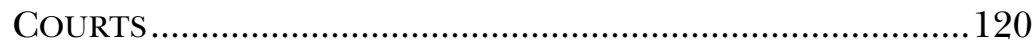

A. Specialized Judges and Courts in the Federal Judiciary .........120

B. The Three-Judge District Court as the Forum for

Constitutional Challenges, 1937-1976.....

III. THE RISE OF STATUTES WITH SPECIALIZED

Constitutional REVIEW Provisions ................................ 128

A. The New Provisions .......................................................128

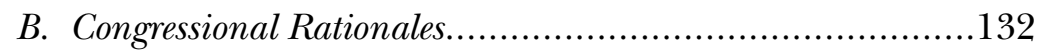

IV. The Dubious Revival of SPECIALIZEd Federal

CONSTITUTIONAL COURTS ................................................... 134

A. Institutional Responsibilities of Congress.........................136

1. Congressional Delegation to the Courts ...................... 136

2. Congressional Cooperation with the Courts................. 138

B. Institutional Effects on the Courts ..................................142

1. Specialization and Percolation ................................ 142

2. Exclusive Jurisdiction in the District of Columbia Circuit............................................................ 148

3. Trials by Three Judges, Expediting Decisions, and Supreme Court Docket Control................................ 152

C. Reconsidering the Constitutional Doubt Canon ...................156

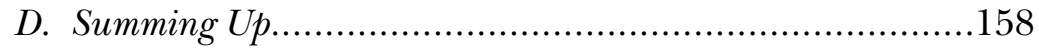

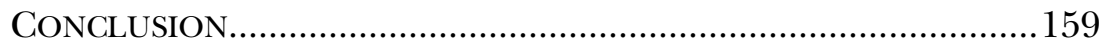


The modern Congress sails close to the wind all the time. Federal statutes today often all but acknowledge their questionable constitutionality with provisions for accelerated judicial review [and] for standing on the part of members of Congress ....

Antonin Scalia \& Bryan A. Garner ${ }^{1}$

\section{INTRODUCTION}

Two of the most contentious and controversial decisions of the United States Supreme Court in recent years, National Federation of Independent Business v. Sebelius ${ }^{2}$ and Citizens United v. FEC ${ }^{3}$ share many common characteristics. Both were 5-4 decisions respectively upholding and striking down high-profile legislative enactments of Congress as a matter of constitutional law, which garnered enormous attention during the litigation processes and after the decisions. Scores of amicus curiae briefs were filed in both cases. Public debate before and after the decisions focused on the predicted and presumed ideological voting of the Justices and on the effect of the decisions on the economy and the political system, respectively. ${ }^{4}$

But the cases differed in important respects: in how they were litigated and how they reached the Supreme Court. NFIB v. Sebelius was decided as are most constitutional challenges to federal statutes. Suit was brought by private parties before a single judge in a U.S. District Court, seeking a ruling that the individual mandate of the Affordable Care Act was unconstitutional. The judge held for the plaintiffs, and the government appealed to the regional U.S. Court of Appeals. Upon losing there, the government filed a writ of certiorari in the Supreme Court, which the Court granted. ${ }^{5}$ Parallel litigation by other

1 Antonin Scalia \& Bryan A. Garner, REading LaW: The Interpretation of Legal TEXTs 248 (2012) (footnotes omitted).

2132 S. Ct. 2566 (2012) (upholding individual mandate of the Affordable Care Act of 2010).

3558 U.S. 310 (2010) (striking down provision of Bipartisan Campaign Reform Act of 2002, which limited independent expenditures by corporations during political campaigns).

4 For discussions of the significance of these decisions in the Roberts Court, see, e.g., David M. O'Brien, Storm Center: The Supreme Court in American Politics 230-31 (10th ed. 2014) (discussing the role of amicus briefs in Citizens United); Pamela S. Karlan, Democracy and Disdain, 126 HARV. L. REv. 1, 29 (2012) (discussing the implications of Citizens United); Jeffrey Rosen, Can the Judicial Branch be a Steward in a Polarized Democracy?, DÆDALus, 25, 25 (2013) (discussing the "ideological lines" of the Roberts Court).

$5 \quad$ Florida ex rel. Bondi v. U.S. Dep't of Health $\mathcal{E}$ Human Servs., 780 F. Supp. 2d 1256 (N.D. Fla. 2011), aff'd in part, rev'd in part_sub nom., Florida ex rel. Atty. Gen. v. U.S. Dep't of Health $\mathcal{E} 0$ Human Servs. 648 F.3d 1235 (11th Cir. 2011), aff'd in part, rev'd in part sub nom., Nat'l Fed'n of Indep. Bus. v. Sebelius, 132 S. Ct. 2566 (2012). 
parties proceeded in other district courts and courts of appeals, and, indeed as the Court noted, those cases generated a split of authority on the constitutionality of the Act. ${ }^{6}$

Citizens United proceeded on a different litigation path. In the Bipartisan Campaign Finance Act (BCRA), Congress had included a provision that mandated that any constitutional challenge to the Act be brought before a three-judge district court convened in the District Court for the District of Columbia, with a direct appeal of any decision to the Supreme Court. ${ }^{7}$ That provision also granted members of Congress standing to bring suit to challenge the Act, and further mandated that the federal courts expeditiously resolve the suit. ${ }^{8}$ Suit was brought by, among others, the then-minority leader of the Senate, and the Act was upheld by a three-judge district court in the District of Columbia. No other litigation was or could be filed, so no district—or circuit—split existed. The Supreme Court, as it usually does with ostensibly mandatory appeals, noted probable jurisdiction in the case, set it for briefing and oral argument, and decided it on the merits. ${ }^{9}$

The special jurisdictional provisions of the BCRA are not an isolated phenomenon. In the past several decades Congress has enacted more than a dozen of these provisions (similar or identical to those in the BCRA) in other statutes, and considered their adoption in other bills introduced but not passed in Congress. ${ }^{10}$ These provisions in effect create specialized federal constitutional courts, temporarily convened with borrowed federal judges for the sole purpose of deciding the constitutionality of a federal statute. They raise important issues of the law and policy of federal courts. For example, why does Congress pass these provisions, and do they have virtues (or vices) not shared with the normal litigation process? Are Justice Antonin Scalia and Professor Bryan Garner right to conclude that the presence of these provisions shows that the underlying statute is of dubious constitutionality? ${ }^{11}$ Are cases before specialized courts qualitatively de-

6 Sebelius, 132 S. Ct. at 2581 (listing other circuits that "have also heard challenges to the individual mandate").

7 Pub. L. No. 107-155, § 403(a), 116 Stat. 81, 113-14 (2002) (codified at 2 U.S.C. § 437h).

$8 \quad I d$. at $\$ 403(\mathrm{a})-(\mathrm{c}), 116$ Stat 113-14.

9 Citizens United v. FEC, 530 F. Supp. 2d 274 (D.D.C. 2008) (three-judge court) (per curiam), appeal dismissed, 552 U.S. 1278 (2008), reargument ordered on appeal after remand, 557 U.S. 932 (2009), aff'd in part, rev'd in part, 558 U.S. 310 (2010).

10 Listings of both are found in infra Part III.

11 Scalia and Garner list a third characteristic commonly found in these special review provisions, which are "fall-back dispositions should the primary disposition be held unconstitutional." SCALIA \& GARNER, supra note 1, at 249. Fall-back provisions are found in statutes 
cided differently than constitutional challenges litigated in the normal process? There has been relatively little sustained discussion of these issues in the scholarly literature, ${ }^{12}$ and this Article begins to fill that gap.

The Article proceeds as follows. Part II addresses the use of specialized courts in the federal system. Such courts are now prevalent for unique areas of subject matter, but have historically been rare for constitutional challenges to federal statutes. In 1937 Congress mandated that all such challenges be brought before a three-judge district court convened in an appropriate venue in the United States, with a direct appeal to the Supreme Court. Congress abolished the threejudge court provision in 1976 and repealed the mandatory appeal for such cases in 1988. Part III of the Article documents the revival of such provisions in the three decades since. The legislative history of those provisions, such as it is, indicates that some members of Congress were unsure of the constitutionality of the underlying statute. Moreover, it also indicates some members of Congress seemed to think that special review provisions would lead to an appropriate and prompt resolution of the issue by the Supreme Court.

Part IV of the Article subjects the passage and use of these provisions to critical analysis. This Part first examines the reasons Congress passes special review provisions. None of them are particularly persuasive reasons to depart from the usual judicial review process, and Congress has not added these provisions in a consistent way to the entire range of federal statutes potentially subject to constitutional attack. The special review provisions seem emblematic of Congress frequently discarding its responsibility to independently consider the constitutionality of statutes. Likewise, a complex and even contradic-

both establishing, and not establishing, special review provisions. While not unrelated to the issues addressed here, further discussion is beyond the scope of this Article. For further discussion, see Michael C. Dorf, Fallback Law, 107 ColuM. L. REv. 303, 304 (2007) (highlighting constitutional and policy concerns regarding the use of fallback provisions in legislation).

12 The special review provisions are discussed in Neal Devins, Congress as Culprit: How Lawmakers Spurred on the Court's Anti-Congress Crusade, 51 DukE L.J. 435, $442-44$ (2001); Neal Devins \& Michael A. Fitts, The Triumph of Timing: Raines v. Byrd and the Modern Supreme Court's Attempt to Control Constitutional Confrontations, 86 GEO. L.J. 351, 356-57 (1997); Elizabeth Garrett \& Adrian Vermeule, Institutional Design of a Thayerian Congress, 50 DukE L.J. 1277, 1311 (2001); Joshua Panas, Note, Out of Control?: Congressional Power to Shape Judicial Review of New Legislation, 1 GEO. J. L. \& PUB. POL'Y 151, 151 (2002). Provisions calling for expeditious court resolution are discussed in William F. Ryan, Rush to Judgment: A Constitutional Analysis of Time Limits on Judicial Decisions, 77 B.U. L. REV. 761, 763 (1997) ("[T] he Habeas Reform Act requires a court of appeals to take no more than thirty days to dispose of a prisoner's motion ...."). 
tory set of reasons by supporters and opponents of a particular statute may account for these provisions. For example, opponents of a statute may support inclusion of the provisions to make it easier and quicker for a court to strike it down.

Part IV next addresses the frequent practice of vesting exclusive jurisdiction in the federal courts in the District of Columbia. The specialized jurisdiction of that court in other matters, such as administrative law, may well be justified, but it does not support similar geographic specialization for constitutional matters. Except for some unique topics, like patent law, the federal judiciary has long resisted geographic specialization, and the use of the District of Columbia courts in this instance violates the norm of regional dispersion of the jurisdiction of trial courts and courts of appeals.

Finally, Part IV analyzes the special review provisions from the perspective of their effect on Supreme Court decision-making. This Part argues that the Court typically benefits from the percolation of issues in different federal courts, and the special review provision deprives the Court of information possibly gained from that percolation. The expeditious review mandate often found in these provisions is unnecessary, since federal judges in the usual process are capable of rapid trial and appeals decisions when necessary. Congress had good reasons to abolish the three-judge district court for constitutional attacks on federal statutes in 1976, and these new provisions improperly revive those courts. Nonetheless, the presence of a special review provision is not egregious enough to reverse the presumption of the constitutionality of a federal statute, as hinted at by Justice Scalia and Professor Garner.

\section{The FAll of SPECialized Federal Constitutional Courts}

\section{A. Specialized Judges and Courts in the Federal Judiciary}

The paradigmatic court in the United States federal system is the District Court, one of general jurisdiction able to hear virtually all civil and criminal cases. The U.S. Courts of Appeals and the Supreme Court can be similarly characterized as courts of general jurisdiction. They are staffed by Article III judges, nominated by the President and confirmed by the Senate for a lifetime appointment. While there have been specialized federal courts throughout our history, they have been particularly ascendant in the twentieth century. There are now a large number of full-time specialized federal courts and judges, covering a variety of administrative law topics or unique subject areas. Most are staffed by judges appointed in a variety of ways outside of 
Article III, lacking the lifetime appointments mandated by that part of the Constitution. ${ }^{13}$

There are also some specialized courts staffed by Article III judges. The Court of Appeals for the Federal Circuit and the Court of International Trade are full-time courts consisting of Article III judges. ${ }^{14}$ In addition, there are specialized courts convened on a temporary, ad hoc basis, staffed by borrowed, generalist Article III judges serving in other courts. ${ }^{15}$ The courts convened to hear constitutional challenges to federal statutes, the main focus of this Article, are examples of the latter.

Despite the great variety of specialized courts in the federal system (and their counterparts at the state court level), there are common rationales for their creation. These courts are said to possess virtues unattainable by generalist courts. These virtues include that it is more efficient to have one court and set of judges work on a particular topic, since judges familiar with that topic can dispose of cases more rapidly and easier than the generalist judges. A related virtue is that the quality of the judicial output is higher, since judges in those courts are presumably experts and can be counted on to apply and develop the law more coherently on a particular topic. Still another virtue is uniformity. Generalist courts in different parts of the country may interpret federal law differently, and if litigation on that topic is vested in one court, then the whole country will have the benefit of dealing with one and only one judicial resolution of an issue. ${ }^{16}$

Yet vices can also attend the creation of specialized courts. Judicial selection for such courts may become politicized by interest groups concerned with their output, in ways usually not found in the judicial selection of most generalist courts. Similarly, specialized courts may be captured by a specialized bar for such cases, who may interact frequently in and outside of court with the judges. Constant-

13 For overviews of these specialized federal courts, see RICHARD H. FALLON, JR. ET AL., HART AND WeChSLeR's The Federal CourTS AND THE Federal System 34-41 (6th ed. 2009); Richard L. Revesz, Specialized Courts and the Administrative Lawmaking System, 138 U. PA. L. REV. 1111, 1111-13 (1990).

14 See FAllon ET AL., supra note 13, at 34-35 (discussing the Court of Appeals for the Federal Circuit and the Court of International Trade).

15 Revesz, supra note 13, at 1112 (discussing past and present examples of these courts, including the Temporary Emergency Court of Appeals, the Special Court for the Regional Railroad Reorganization Act of 1973, the Foreign Intelligence Surveillance Court, and the Foreign Intelligence Surveillance Court of Review).

16 For overviews of the benefits of specialized courts, see LAWRENCE BAUM, SPECIALIZING THE COURTs 32-34 (2011); Revesz, supra note 13, at 1116-17. But see Stefan Voigt, On the Optimal Number of Courts, 32 INT'L REV. L. \& ECON. 49, 50-51 (2012) (discussing the costs of having specialized courts and the benefits of multiple court heirarchies). 
ly dealing with one area of law may become monotonous for the expert judges, and it is difficult to objectively measure if a specialized court is issuing higher quality or more coherent decisions than a generalist court dealing with the same cases. ${ }^{17}$

\section{B. The Three-Judge District Court as the Forum for Constitutional Challenges, 1937-1976}

The advent of the administrative state, the increasing number and complexity of federal legislation, and increased caseloads in general have driven the specialization of the federal judiciary. ${ }^{18}$ Yet constitutional litigation has resisted this trend toward specialization. That is, with the exception of the three-judge district court for forty years of the twentieth century, summarized below, there has not been a standing, specialized federal court to deal with constitutional litigation in general or the constitutional challenges to federal statutes in particular.

Such an institution is not as unusual elsewhere in the world. Many other nations have established a standing court for the specific purpose of hearing constitutional challenges to legislation of the national government. Indeed, there has been an increasing trend toward greater use of this centralized method of judicial review, as compared to the typically decentralized path of constitutional litigation in the United States. ${ }^{19}$ Support for "constitutional courts" in other nations has a long pedigree, ${ }^{20}$ but they have become more popular in the post-World War II era due to several factors. New constitutions were adopted in many countries, often with bills of rights, that

17 For an overview of these vices, see BAUM, supra note 16, at 35-41; RICHARD A. POSNER, The Federal Courts: Challenge And Reform 249-58 (1996); Edward K. Cheng, The Myth of the Generalist Judge, 61 STAN. L. REV. 519, 550-60 (2008); Voigt, supra note 16, at $51-52$.

18 For an overview of the increasing specialization of the federal courts in the twentieth century, see Justin Crowe, Building the Judiciary: LAW, COURTS, AND THE POlitics OF INSTITUTIONAL DEVELOPMENT 238-69 (2012).

19 See Alec Stone Sweet, Constitutional Courts, in The Oxford Handbook of Comparative Constitutional LaW 816, 817 (Michel Rosenfeld \& András Sajó eds., 2012) ("For reasons to be discussed, the framers of new constitutions have been more attracted to the 'centralized model' of constitutional review, with a specialized [constitutional court] at its core, than to the 'decentralized (or American) model' of judicial review exercised by the judiciary as a whole."); Nuno Garoupa \& Tom Ginsburg, Building Reputation in Constitutional Courts: Political and Judicial Audiences, 28 ARIZ. J. INT'L \& COMP. L. 539, 539 (2011) ("Specialized constitutional courts have expanded all over the world in recent decades.").

20 The earliest and most influential supporter in the mid-twentieth century for constitutional courts was Austrian legal theorist Hans Kelsen. See Sweet, supra note 19, at 817-19 ("The modern constitutional court, however, is largely the invention of Hans Kelsen."). 
benefited from a judicial enforcement mechanism. A stand-alone constitutional court could be easily added to existing judicial structures. Many countries were experimenting for the first time with American-style judicial review, and constitutional courts dedicated to that purpose were thought appropriate for the advancement and legitimacy of that project. ${ }^{21}$

But for the most part the United States has been reticent to establish a standing constitutional court. Part of the explanation is surely the relatively recent practice, in historical terms, of the Supreme Court regularly considering the constitutionality of federal statutes. While that power of course traces back over two centuries to Marbury v. Madison, ${ }^{22}$ for much of American history the Supreme Court has not been hearing constitutional challenges to, much less stricken down, congressional legislation. During most of the nineteenth century the Court rarely was asked to strike down, and rarely did strike down, federal legislation as unconstitutional. That reticence eroded in the late nineteenth century, and the erosion has continued to greater or lesser degrees since then. ${ }^{23}$ But the present, three-tier structure of the generalist Article III courts was in place by $1891,{ }^{24}$ and it appears there was little if any discussion after that point about creating specialized constitutional courts in the federal system.

That discussion revived in the 1930s during the Court's storied battle with President Franklin Roosevelt regarding the constitutionality of several important pieces of New Deal legislation. The President's "court-packing" proposal had been largely framed in administrative terms, to enable the Supreme Court and the federal court system to operate in a more efficient manner. The proposal to pack

21 See id. at 819-20 (discussing constitutional framers from various countries that model their systems after those found in other countries). One recent study has concluded that the adoption of such courts is best explained by domestic political considerations, namely, as a method where competitive political parties seek to safeguard their future interests. They do this in the belief that the judiciary may protect constitutional values even when a particular party lacks, at least periodically, the political power to do so. See generally Tom Ginsburg \& Mila Versteeg, Why Do Countries Adopt Constitutional Review?, 30 J. L. ECON. \& ORG. 587 (2014).

225 U.S. (1 Cranch) 137 (1803).

23 For overviews and data on the Supreme Court deciding constitutional challenges to congressional legislation, see LEE EPSTEIN ET AL., THE SuPREME COURT COMPENDIUM: DATA, DECISIONS, AND DEVELOPMENTS 188-92 (5th ed. 2012) (publishing a table of "Supreme Court Decisions Holding Acts of Congress Unconstitutional in Whole or in Part, 17892009 Terms"); see generally, Linda Kamp KeITH, The Supreme COURT AND THE Judicial REVIEW OF CONGRESS (2008).

24 This was as a result of the Evarts Act of 1891, creating the regional U.S. Courts of Appeals. The present structure of regional district courts and appellate courts continued relatively unchanged since then. FALLON ET AL., supra note 13, at 37-38. 
the Court by adding Justices spectacularly failed, but a relatively minor part of that package did pass Congress in 1937. It required that all constitutional challenges be filed before a three-judge district court with venue over the action. ${ }^{25}$ The judges of that court consisted of the district judge before whom the case was originally filed, supplemented by at least one court of appeals judge, and typically another district judge, the latter two appointed by the Chief Judge of the circuit within which the suit was brought. A direct appeal was possible to the Supreme Court; the Court ostensibly had to hear the appeal, as it was different from the discretionary certiorari jurisdiction which covered almost all of the Court's other cases.

The three-judge court concept was borrowed virtually unchanged from the three-judge district court Congress established in 1910 to hear constitutional challenges to, and particularly, to seek injunctive relief against, state statutes. The 1910 law was a reaction to the thencontroversial Court decision in 1908 in Ex parte Young, ${ }^{26}$ in which the Lochner Era Court struck down state Progressive Era legislation regulating railroad rates. What was especially noteworthy about Ex parte Young was that the Court permitted the plaintiff railroad companies to proactively seek injunctive relief in federal court, rather than wait to raise the constitutional issue as a defense to an enforcement action in state court. ${ }^{27}$ In reaction, Congress legislatively mandated that all such actions, seeking injunctive relief on the asserted basis of the unconstitutionality of a state statute, be brought before a specially convened three-judge district court, with a direct appeal to the Supreme Court. ${ }^{28}$ Supporters in Congress advanced several rationales for this court to hear such matters. The striking down of a state statute on these grounds was considered so significant that one federal judge, standing alone, should not possess the power to do so. Instead, any such decision would be better discussed and decided by three federal judges, at least one of whom was a court of appeals judge, and perhaps even better received by the interested public. Whatever the decision of the three-judge district court, supporters also thought that a prompt resolution of an important matter like the legality of a state statute was necessary, and one way to ensure that would be to bypass

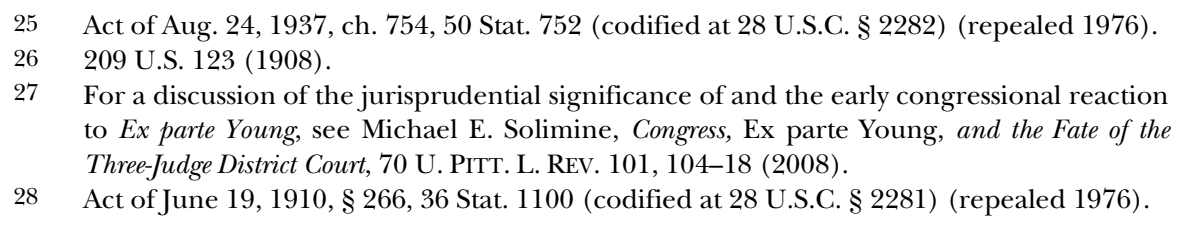


the normal appeal to a court of appeals, and provide a direct path to the Supreme Court. ${ }^{29}$

In the years leading up to 1937, many federal laws challenged on constitutional grounds were the subject of injunctions entered by federal judges in lower courts, most on their way to review by the Supreme Court. As early as 1935 some members of Congress, "irritat $[\mathrm{ed}]{ }^{, 30}$ by how some federal judges, sitting alone, had enjoined enforcement of what were perceived to be important federal statutes, supported proposals to provide for prompt, direct appeals of such decisions to the Supreme Court. These ideas led to the legislation in 1937, whose supporters argued that litigation attacking federal statutes should be of "equal dignity" to other suits covered by the threejudge district court and share in the presumed benefits of that court. $^{31}$

Whatever the benefits of the three-judge district court to litigants, particularly plaintiffs, ${ }^{32}$ many other influential observers eventually concluded that they were outweighed by the administrative burdens of the court. ${ }^{33}$ The criticisms were very similar for both aspects of the

29 For detailed discussion of the legislative background and intent of the 1910 Act, see Solimine, supra note 27 , at 111-18.

30 Felix Frankfurter \& Adrian S. Fisher, The Business of the Supreme Court at the October Terms, 1935 and 1936, 51 HARV. L. REv. 577, 617 (1938). There was a "voluminous outpouring" of federal district court decisions holding various provisions of New Deal legislation unconstitutional and enjoining their application. Id. at 611. One of the leading Congressional critics of these decisions was then-Senator Hugo Black, who introduced legislation in 1935 providing for direct appeals from district court decisions, though not for the convening of a three-judge district court. Id. at $612-13$. The legislation proposed by Senator Black did not pass. Id. at 613 .

31 David P. Currie, The Three-Judge District Court in Constitutional Litigation, 32 U. CHI. L. ReV. 1,11 (1964). For further discussion of the legislative history of the 1937 Act, see CHARLES Alan Wright et Al., 17A Federal Practice and Procedure $\$ 4234$ at 194-95 (3d ed. 2007); Frankfurter \& Fisher, supra note 30, at 610-19; Solimine, supra note 27, at 124-25; Comment, The Three-Judge Federal Court in Constitutional Litigation: A Procedural Anachronism, 27 U. CHI. L. REV. 555, 561-63 (1960).

32 For example, plaintiffs in civil rights cases in the 1950s and 1960s saw benefits in litigating cases before the court, particularly those brought in southern states. In many instances, they thought, they were more likely to prevail before three judges than before a possibly recalcitrant single judge. And they preferred a relatively quick appeal to what was perceived as a friendly tribunal (the Warren Court), as compared to the normal and longer appeals process to a less certain fate in one of the courts of appeals. See Solimine, supra note 27, at 125-31 (discussing "[t]he Three-Judge District Court and the Civil Rights Movement").

33 Concern over the administrative burdens of the court began to be expressed soon after its jurisdiction was extended to attacks on federal statutes and only intensified later. See e.g., Phillips v. United States, 312 U.S. 246, 250 (1941) (noting that the three-judge district court "entails a serious drain upon the federal judieial system particularly in regions where, despite modern facilities, distance still plays an important part in the effective administration of justice"). 
court, as it pertained to attacks on federal and state statutes. One criticism was the administrative burdens placed on the lower courts. Most cases then and now are litigated in the first instance before a single district judge. Assembling three federal judges to sit as a trial court was an awkward fit on several grounds. The busy schedules of three otherwise separately-working judges had to be reconciled; trial judges and at least one appeals judge, used to working separately, had to work together; and three persons rather than just one had to perform the work typically done by one trial judge. ${ }^{34}$

Another criticism concerned the caseload of the Supreme Court. Normally the Court manages its discretionary docket through the writ of certiorari, but direct appeals bypassed this process and ostensibly required the Court to decide all such appeals on the merits. It deprived the Court of the possible benefit of consideration and sharpening of issues by at least one, and sometimes more than one, court of appeals, as with all other cases. Nor was a direct appeal necessary for rapid disposition, critics argued, since experience showed that when necessary district and appellate judges could expeditiously decide cases and appeals. The Court ameliorated some of these problems by often summarily affirming (or occasionally reversing) such appeals, as opposed to setting them for a full briefing and argument, followed by a full opinion. But even with this safety valve, the Court was deciding scores of appeals from three-judge district courts in the 1960 s and 1970 s, sometimes up to a third of all decisions rendered in a Term. ${ }^{35}$

By that time, prominent academic observers, ${ }^{36}$ think tanks, ${ }^{37}$ and specially appointed committees ${ }^{38}$ were calling for the abolition of the

34 E.g., Currie, supra note 31, at 2, 74 (recognizing as a "prejudice" against provisions providing for three-judge district courts and direct appeal to the Supreme Court that "[c]onsuming the energies of three judges to conduct one trial is prima facie an egregious waste of resources"); FEDERAL JUDICIAL CENTER, REPORT OF THE STUDY GROUP ON THE CASELOAD OF THE SUPREME COURT (1972), reprinted in 57 F.R.D. 573, 598-99 (1973) [hereinafter FREUND REPORT].

35 E.g., Am. Law Inst., Study of the Division Between State and Federal Courts 53, 318-25 (1969) [hereinafter ALI STUDY] (citing some cases that addressed three-judge courts); FREUND REPORT, supra note 34, at 599-602. One problem raised by the summary disposition practice was how much precedential weight they should be given by the Court itself and lower courts. To this day the Court itself has been unclear on this matter. See Solimine, supra note 27, at 135 .

36 For example, Professor David Currie of the University of Chicago. See supra note 31.

37 For example, the American Law Institute. See supra note 35.

38 For example, the committee assembled under the auspices of the Federal Judicial Center, chaired by Harvard Law Professor Paul Freund, and including Professors Alexander Bickel (Yale Law School) and Charles Alan Wright (University of Texas Law School), among others. See supra, note 34 . 
thee-judge district court, as least as it pertained to constitutional attacks on federal statutes. This criticism was joined by prominent federal judges, not least of whom was Chief Justice Warren Burger. ${ }^{39}$ The Judiciary Committees in both houses of Congress listened to their pleas, held hearings and passed bills ${ }^{40}$ culminating in legislation enacted in $1976,{ }^{41}$ which abolished the court as it pertained to attacks on federal statutes. The legislation significantly curtailed its usage in attacks on state practices, as it was only to be convened for reapportionment cases. ${ }^{42}$ The 1937 experiment had come to end, and few seemed to mourn its passing. ${ }^{43}$

39 Chief Justice Warren E. Burger, The State of the Federal Judiciary-1972, 58 A.B.A.J. 1049, 1053 (1972) ("We should totally eliminate the three-judge district courts that now disrupt district and circuit judges' work.").

40 For a detailed summary and examination of the consideration and passage of the 1976 Act, see WRIGHT, supra note 31 , at $\$ 4235$; Solimine, supra note 27 , at 134-48.

41 Act of Aug. 12, 1976, Pub. L. No. 94-381, 90 Stat. 1119 (codified in part at 28 U.S.C. $\S$ 2284).

42 The critics of the three-judge district had allowed that it still might be appropriate for particularly controversial cases raising federalism issues, and reapportionment cases were listed as an example. See Solimine, supra note 27, at 137-38 (discussing views of Professor Currie and of the ALI Report). That proposed exception was later considered by the Judiciary Committees, and it found its way into the final legislation. Id. at 144 ("The reports of the Senate and House Judiciary Committees make clear that the drafters of those reports adopted almost all the arguments of the critics of the three-judge district court."). The principal reason for that exception was the then-controversial nature of reapportionment cases in federal court, initiated by Baker v. Carr, 369 U.S. 186 (1962). Id. at 14445 ("Also, reapportionment cases were, at the time, particularly controversial. Baker $v$. Carr and legislative efforts to restrict it were probably fresh in the minds of many members of Congress."). For discussions of litigation in three-judge district courts in reapportionment and related cases since 1976, see Michael E. Solimine, Congress, the Solicitor General, and the Path of Reapportionment Litigation, 62 CASE W. RES. L. REV. 1109, 1141-47 (2012) [hereinafter Solimine, Reapportionment]; Michael E. Solimine, The Three-Judge District Court in Voting Rights Litigation, 30 U. MICH. J.L. REFORM 79 (1996) [hereinafter Solimine, Three-Judge District Court]; see also Lisa Marshall Manheim, Redistricting Litigation and the Delegation of Democratic Design, 93 B.U. L. REv. 563 (2013).

43 The remnant of the direct review statute, insofar as it did not apply to the remaining three-judge district court jurisdiction, was repealed in 1988. See Act of June 27, 1988, Pub. L. No. 100-352, 102 Stat. 662. For a discussion of this, see 17 WRIGHT ET AL., supra note 31 , at $\S 4040$. While proposals to repeal the direct review statute were discussed at the same time as proposals to repeal the three-judge district court, the latter preceded the former by twelve years. The principal reason for the delay was that early in the Reagan Administration, proposals to repeal the direct review statute were coupled with amendments to deprive the Supreme Court of any review over cases involving certain controversial issues, such as school prayer. Such amendments were themselves so controversial that support for a simple repeal suffered. Eventually those amendments were dropped and a straightforward repeal passed. See Tara Leigh Grove, The Exceptions Clause as a Structural Safeguard, 113 Colum. L. REv. 929, 970-76 (2013) (discussing the debates over "the Supreme Court's certiorari jurisdiction" and their results). 


\section{THE RISE OF STATUTES WITH SPECIALIZED CONSTITUTIONAL REVIEW PROVISIONS}

\section{A. The New Provisions}

Even before the 1976 repeal of the three-judge district court, Congress was considering and enacting legislation that replicated, in whole or in part, the repealed provision in the context of particular statutes. And that process continued for an appreciable number of statutes after the 1976 repeal. This Part of the Article will first provide an overview of those statutes and then summarize the legislative history of the provisions.

One category of these statutes is those concerning the regulation of fund-raising by various entities for political campaigns for federal office. In the 1974 amendments to the Federal Election Campaign Act (FECA), Congress provided that the "national committee of any political party," or "any individual eligible to vote in any election for the office of the President," could file suit challenging the constitutionality of the amendments in an appropriate federal district court. ${ }^{44}$ The court was to "immediately" certify all constitutional questions to the relevant court of appeals, which was directed to hear the appeal en banc. ${ }^{45}$ That decision would be reviewed on direct appeal in the Supreme Court. The legislation further admonished the federal courts to hear and decide the cases expeditiously. ${ }^{46}$ Senator James Buckley, a vocal opponent of the amendments, promptly brought suit in the district court for the District of Columbia, and the indicated provisions were utilized in the litigation that culminated in the landmark case of Buckley $v$. Valeo. ${ }^{47}$

44 Federal Election Campaign Act Amendments of 1974, Pub. L. No. 93-443, § 315(a), 88 Stat. 1285 (1974) (codified at 2 U.S.C. $\$ 437 \mathrm{~h}$ ).

$45 \quad I d$.

46 Id. An earlier, related law, the Presidential Election Campaign Fund Act of 1971, established an exclusive mechanism for the FEC and others to "implement or construe" the law. Pub. L. No. 92-178, 85 Stat. 563, 570 (1971) (codified as amended at 26 U.S.C. § 9011 (b) (1)). Suit would be brought before a three-judge district court, with a direct appeal to the Supreme Court. Id. (codified as amended at 26 U.S.C. § 9011(b) (2)). The statutory text did not specifically refer to a constitutional challenge, but such a challenge was resolved through litigation under that provision. See Common Cause v. Schmitt, 512 F. Supp. 489, 490, 494 (D.D.C. 1980) (presiding as a three-judge court and analyzing the constitutionality of the limits imposed by the Presidential Election Campaign Fund Act of 1971), aff'd, 455 U.S. 129 (1982).

47424 U.S. 1 (1976) (per curiam). For further discussion of the passage of the amendments and the procedural aspects of the Buckley $v$. Valeo case, see Michael E. Solimine, Institutional Process, Agenda Setting, and the Development of Election Law on the Supreme Court, 68 Оніо Sт. L.J. 767, 771, 775 (2007) [hereinafter Solimine, Institutional]. 
A similar but not identical pattern is found in the special review provisions of the Bipartisan Campaign Reform Act (BCRA) of 2002, ${ }^{48}$ mentioned at the outset of this Article, also known as the McCainFeingold law. Section 403 of the BCRA provides that any constitutional challenge must be brought before a three-judge district court in the District of Columbia, with a direct appeal to the Supreme Court, and in an expedited manner. ${ }^{49}$ It further provided that members of Congress had standing to challenge the law in court, or could intervene in similar litigation brought by others. ${ }^{50}$ Intervention was unnecessary, as then-Minority Leader Senator Mitch McConnell and other members of Congress brought suit the day after the President signed the BCRA, starting the process that culminated in the Supreme Court's decision of McConnell v. Federal Election Commission. ${ }^{51}$ These provisions have also been used by other plaintiffs challenging other aspects of the BCRA, which have resulted in additional cases litigated in the District of Columbia and the Supreme Court, ${ }^{52}$ including Citizens United v. Federal Election Commission. ${ }^{53}$

A second set of statutes do not fall into any particular subject area, but can be categorized as legislation that at least some members of Congress deemed important and would benefit from constitutional challenges being litigated in the pattern found in the BCRA: exclusive review by a single judge or a three-district court, usually in the

48 Pub. L. No. 107-155, 116 Stat. 81 (2002). The BCRA thus amended the FECA, but established a different review mechanism for constitutional questions. Constitutional challenges to provisions of FECA remain under the procedure passed in 1974. See Wagner v. FEC, 717 F.3d 1007, 1010-11, 1015 (D.C. Cir. 2013) (per curiam) (discussing the ways in which constitutional challenges to FECA must be reviewed).

49 Bipartisan Campaign Reform Act $§ 403$ (a).

$50 \quad I d$. at $\S 403(\mathrm{~b})$.

51540 U.S. 93 (2003), aff'g in part, rev'g in part, 251 F. Supp. 2d 176 (D.D.C. 2003) (threejudge court) (per curiam). For an overview of the procedural aspects of McConnell, see Solimine, Institutional, supra note 47, at 771-72, 776.

52 See, e.g., Wisconsin Right to Life, Inc. v. FEC, 546 U.S. 410 (2006), vacating 2004 WL 3622736 (D.D.C. 2004) (three-judge court); FEC v. Wisconsin Right to Life, Inc., 551 U.S. 449 (2007), aff'g 466 F. Supp. 2d 195 (D.D.C. 2006) (three-judge court); Davis v. FEC, 554 U.S. 724 (2008), rev'g 501 F. Supp. 2d 22 (D.D.C. 2007) (three-judge court); Republican Nat'l Comm. v. FEC, 130 S. Ct. 3544 (2010), aff'g 698 F. Supp. 2d 150 (D.D.C. 2010) (three-judge court); Bluman v. FEC, 132 S. Ct. 1087 (2012), aff'g 800 F. Supp. 2d 281 (D.D.C. 2011) (three-judge court)); McCutcheon v. FEC, 134 S. Ct. 1434 (2014), rev'g 893 F. Supp. 2d 133 (D.D.C. 2012) (three-judge court); James v. FEC, 134 S. Ct. 1806 (2014) (per curiam), vacating and remanding 914 F. Supp.2d 1 (D.D.C. 2012) (three-judge court); see also Nicholas Confessore, G.O.P. Sues for a Loophole to Raise Unlimited Money from Individuals, N.Y. TimEs, May 24, 2014, http://www.nytimes.com/2014/05/24/us/politics/ gop-sues-in-effort-to-raise-unlimited-cash-from-individuals.html?_r=0 (discussing the latest suit against the BCRA, Republican Nat'l Comm. v. FEC).

53558 U.S. 310 (2010). For the procedural history of the decision, see supra note 9. 
District of Columbia, followed by direct review in the Supreme Court. $^{54}$ These statutes include the Balanced Budget and Emergency Deficit Control (Gramm-Rudman-Hollings) Act of $1985,{ }^{55}$ the Cable Television Consumer Protection and Decency Act of $1992,{ }^{56}$ the Communications Decency Act of $1996,{ }^{57}$ the Telecommunications Act of $1996,{ }^{58}$ the Line Item Veto Act of $1996,{ }^{59}$ and the census reform legislation passed in $1998 .^{60}$ Two other statutes similarly provided that a constitutional challenge must be brought before a single district judge in a district with appropriate venue, with a direct appeal and certiorari jurisdiction, respectively, to the Supreme Court: the Flag Protection Act of $1989,{ }^{61}$ and the REAL ID Act of $2005 .{ }^{62}$

54 These statutes were assembled in two ways, by consulting secondary sources which list examples of such laws, e.g., SCALIA \& GARNER, supra note 1, at 248-29 nn. 7-9, and conducting a computer search of the text of statutes and bills for the past six Congresses found at www.thomas.gov, now www.congress.gov, for the words "constitutional" or "constitutionality." I cannot guarantee that I have found every law that contains a special provision for constitutional challenges, but I believe I account for many if not most of them.

55 Pub. L. No. 99-177, § 274(a) (5), 99 Stat. 1037, 1098 (1985), applied in Bowsher v. Synar, 478 U.S. 714, 734 (1986) (holding the law unconstitutional), aff'g Synar v. United States, 626 F. Supp. 1374 (D.D.C. 1986) (three-judge court)

56 Pub. L. No. 102-385, § 23, 106 Stat. 1460, 1500, applied in Turner Broad. Sys., Inc. v. FCC, 512 U.S. 622, 622 (1994) (remanding case for further proceedings), vacating 819 F. Supp. 32 (D.D.C. 1993) (three-judge court), and Turner Broad. Sys., Inc. v. FCC, 520 U.S. 180, 225 (1997) (holding "must-carry" provisions constitutional), aff'g 910 F. Supp. 734 (D.D.C. 1995) (three-judge court).

57 Pub. L. No. 104-104, § 561, 110 Stat. 133, 142, applied in Reno v. ACLU, 521 U.S. 844, 885 (1997) (holding law that limited indecent material on internet unconstitutional), aff'g 929 F. Supp. 824 (E.D. Pa. 1996) (three-judge court).

58 Pub. L. No. 104-104, §561 (a), 110 Stat. 56, 142, applied in United States v. Playboy Entm't Grp., Inc., 529 U.S. 803, 827 (2000) (holding that part of the law is unconstitutional as violating First Amendment), aff'g 30 F. Supp. 2d 702 (D.Del. 1998) (three-judge court).

59 Pub. L. No. 104-130, § 3, 110 Stat. 1200, 1211 (1996), applied in Raines v. Byrd, 521 U.S. 811, 830 (1997) (establishing members of Congress did not have standing to challenge law), vacating 956 F. Supp. 25 (D.D.C. 1997), and Clinton v. City of New York, 524 U.S. 417, 449 (1998) (holding line-item veto unconstitutional as violation of separation of powers), aff'g 985 F. Supp. 168 (D.D.C. 1998).

60 Departments of Commerce, Justice, and State, the Judiciary, and Related Agencies Appropriations Act of 1998, Pub. L. No. 105-119, § 209(e), 111 Stat. 2240, 2480, applied in Dep't of Commerce v. U.S. House of Representatives, 525 U.S. 316, 320 (1999) (challenging constitutionality of sampling to generate census data since statute was interpreted not to provide for sampling), aff'g Glavin v. Clinton, 19 F. Supp. 2d 543 (E.D. Va. 1998) (three-judge court) and U.S. House of Representatives v. U.S. Dept. of Commerce, 11 F. Supp. 2d 76 (D.D.C. 1998) (three-judge court).

61 Pub. L. No. 101-131, § 3, 103 Stat. 777, applied in United States v. Eichman, 496 U.S. 310, 312 (1990) (holding law unconstitutional), aff'g 731 F. Supp. 1123 (D.D.C. 1990) and United States v. Haggerty, 731 F. Supp. 415 (W.D. Wash. 1990).

62 Pub. L. No. 109-13, 119 Stat. 311, construed in Defenders of Wildlife v. Chertoff, 527 F. Supp. 2d 119, 121 (D.D.C. 2007) (granting the defendants' motion to dismiss and rejecting the constitutional challenge), cert. denied, 554 U.S. 918 (2008). 
A third set of statutes can be collectively labeled as "Saxbe Fix" laws. The term comes from controversy surrounding President Nixon's nomination in 1973 of Senator William Saxbe to serve as Attorney General. Since Saxbe served in Congress while legislation passed to increase the salary or benefits of the office to which he would be appointed, it was argued that the appointment would violate the obscure Emoluments Clause of the Constitution. ${ }^{63}$ The issue has come up numerous times in American history, and the response has ranged from nothing, to statutes which retroactively reduce any salary or benefits flowing to the office of the new appointee, as occurred with Attorney General Saxbe. ${ }^{64}$ Some have argued, however, that the retroactive fix does not cure an Emoluments Clause violation, and on at least five occasions the legislation has provided a special review process for an anticipated constitutional attack. Four of those laws required that such a suit be brought before a three-judge district court in the District of Columbia, with a direct appeal to the Supreme Court. $^{65}$ At least one other law set up the same process, but with no requirement that it be brought in the District of Columbia. ${ }^{66}$

Finally, it is worth noting that in recent years bills have been introduced in Congress which, in a variety of circumstances, establish special review mechanisms for anticipated constitutional challenges to the law, if enacted. ${ }^{67}$ Indeed, on one recent occasion the lack of

63 U.S. CONST. art. I, § 6, cl.2.

64 For a history of the controversy, see Michael Stokes Paulsen, Is Lloyd Bentsen Unconstitutional?, 46 STAN. L. REV. 907 (1994).

65 For the appointment of Sen. Hillary Clinton to Secretary of State, see Pub. L. No. 110455, 122 Stat. 5036 (2008), applied in Rodearmel v. Clinton, 666 F. Supp. 2d 123, 125 (D.D.C. 2009) (three-judge court) (dismissing case for lack of standing), appeal dismissed, 130 S. Ct. 3384 (2010). For the appointment of Sen. Ken Salazar to the Secretary of the Interior, see Pub. L. No. 111-1, 123 Stat. 3 (2009). For the appointment of Sen. Lloyd Bentsen to Secretary of the Treasury, see Pub. L. No. 103-2, 107 Stat. 4 (1993). For the appointment of Senator William Saxbe to Attorney General, see Pub. L. No. 93-178, 87 Stat. 697 (1973).

66 Act of Oct.12, 1979, Pub. L. No. 96-86, § 101(c), 93 Stat. 656, 657-58, applied in McClure v. Carter, 513 F. Supp. 265, 271 (D. Idaho 1981) (three-judge court) (holding provision granting standing to plaintiff Senator unconstitutional and thus not reaching merits), aff'd, McClure v. Reagan, 454 U.S. 1025 (1981). This provision was the result of opposition by Senator James McClure, Republican of Idaho, to the appointment of Democratic Representative Abner Mikva of Illinois to the D.C. Circuit. See Solimine, Three-Judge District Court, supra note 42, at 133 n. 284 (discussing this case).

67 See, e.g., District of Columbia Equal Representation Act of 2013, H.R. 362, 113th Cong. § 7 (2013) (requiring constitutional challenge to be in the district court for the District of Columbia with direct appeal on an expedited basis to the Supreme Court); Main Street Fairness Act, S. 1452, 112th Cong. $\$ 8$ (2011) (requiring a direct appeal to the Supreme Court from the district court, except without a requirement that such a suit be only brought in the District of Columbia); District of Columbia Voting Rights Act of 2009, S. 
such a provision in a proposed law was a subject of controversy on the floor of Congress. In response to the Citizens United decision, Democrats introduced the DISCLOSE Act, which among other things would have strengthened disclosure requirements for campaign contributions. ${ }^{68}$ It also provided that any constitutional challenge be filed in the district court for the District of Columbia, with an appeal to a three-judge panel of the U.S. Court of Appeals for the District of Columbia, combined with permission for members of Congress to file such a suit and a mandate that the federal courts expeditiously resolve the case. ${ }^{69}$ Republican opponents in the House of Representatives denounced the omission of a direct appeal to the Supreme Court, like that found in the BCRA. The omission, the opponents charged, was "an effort to ensure that the Supreme Court would not interpret the law before the 2010 elections." ${ }^{, 70}$ The bill passed the House but ultimately failed in the Senate.

\section{B. Congressional Rationales}

Several common themes are apparent in the passage of almost all of the special review provisions. One characteristic is that the provisions were rarely the subject of extensive (or any) discussion during the typically early stages of the legislative process (i.e., in committee hearings or reports), and instead were added as late amendments, often on the floor of Congress before a final vote. ${ }^{71}$ The provisions were often added to respond to eleventh-hour arguments that the underlying laws were constitutionally suspect. ${ }^{72}$

160, 111th Cong. $\$ 8$ (a) (2009) (requiring any constitutional challenge to be brought in a three-judge district court in the District of Columbia, with a direct appeal to the Supreme Court); Fair Elections Now Act, H.R. 7022, 110th Cong. $§ 401$ (2008) (appeal of "any court ruling" on a constitutional challenge to the law "may be taken directly to the Supreme Court"); Fairness in Asbestos Injury Resolution Act of 2005, S. 852, 109th Cong. § 305 (c) (1) (2005) (requiring any constitutional challenge to be brought in a three-judge district court in the District of Columbia, with a direct appeal to the Supreme Court); District of Columbia Student Opportunity Scholarship Act of 2002, S. 2866 107th Cong. § 12 (2002) (determining constitutional challenge would be in the district court for the District of Columbia, on an expedited basis with a direct appeal to the Supreme Court)

68 Democracy is Strengthened by Casting Light on Spending in Elections Act, H.R. 5175, 111th Cong. (2010) [hereinafter DISCLOSE Act].

69 Id. at $§ 401(\mathrm{a})(1)-(3)$.

70 Joshua A. Douglas, The Procedure of Election Law in Federal Courts, 2011 UTAH L. REv. 433, 476.

71 See Devins, supra note 12, at 442-43 (giving examples of statutes in which "the expedited review provision was not part of the original bill").

72 See id. (" $[\mathrm{I}]$ nstead, after constitutional objections were raised, Congress-rather than settle the issue itself-decided that it was best to hand the matter off to the Supreme 
To the extent the official record reveals putative motivations for the special review provisions, they fall into two related categories. First, there is a desire for swift resolution of any constitutional challenges in federal court to the underlying substantive law, and the concern that the constitutionality of the law is not clear. This goal is ostensibly advanced by the truncated two-step process, typically leaving out an appeal from the district court to the courts of appeals, coupled with mandates that the Supreme Court hear an appeal, and that all of the federal judges expeditiously resolve the case. Members of Congress indicated that there was a need for swift resolution of any court challenges, due to upcoming elections, the cost of implementing the law, or similar reasons. ${ }^{73}$

The second ground is concern over the constitutionality of the law. This is related but separate from the desire to see that a constitutional litigation be promptly resolved. Some members of Congress might be certain that the law is constitutional, but nonetheless concede that not everyone agrees and wish that any litigation by constitutional doubters be quickly resolved against the plaintiffs. That said, the legislative history of the provisions in question indicates concerns of constitutional uncertainty, rather than doubts of lawfulness or firm convictions that the underlying law is constitutional. According to most of these members of Congress, the conventional way to resolve the constitutional question is to make it quicker and easier for federal courts to resolve the issue. ${ }^{74}$

Court."); Panas, supra note 12, at 170-71 (illustrating how this happened in the Line Item Veto Act).

73 Consider the following examples. On the 1974 Amendments to FECA, supra note 46, see Solimine, Institutional, supra note 47 , at 772 ("Given their regulation of campaign finance for presidential and other federal office elections, the drafters thought that a prompt resolution of any legal challenge to these important statutes was desirable."); Panas, supra note 12, at 163-66 (discussing various rationales for expedited review provisions); Wagner v. FEC, 717 F.3d 1007, 1013-15 (D.C. Cir. 2013) (per curiam) (discussing the legislative purpose of FECA). On the costs of implementing the census sampling law in 1998, see supra note 60 and 143 CONG. REC. H8227 (1997) (statement by Rep. Rogers). On the need for prompt resolution of challenges to the changes in the budget procedures found in the Balanced Budget and Emergency Deficit Control Act of 1985, supra note 55, see H.R. REP. No. 99-433, at 99-100 (1985) (Conf. Rep.); 131 ConG. ReC. H9598 (daily ed. Nov. 1, 1985) (statement of Rep. Duncan discussing the Act). And on the need to promptly determine if the President could exercise the powers granted him by the Line Item Veto Act, supra note 59, see 141 ConG. REC. S4243-44 (daily ed. Mar. 21, 1995) (statements of Sens. Simon, Exon, and McCain); Devins \& Fitts, supra note 12, at 357-58 (explaining that "congressional sponsors understood that the President would not have an opportunity to make use of his item veto power until some time after the Supreme Court's anticipated decision").

74 Consider the following examples. On the Balanced Budget and Deficit Control Act of 1985, supra note 55, see 131 CONG. REC. H29050 (daily ed. Oct. 24, 1985) (statement of 
There was not necessarily unanimous support for the provisions. On several occasions the record reveals that some members opposed the special review provisions or were skeptical of their efficacy. The reasons included concerns that the provisions in effect called for the federal courts to render advisory opinions, ${ }^{75}$ or that the constitutional status of the underlying statute was not important enough to be the subject of special treatment, as compared to other laws. ${ }^{76}$

\section{The Dubious Revival of Specialized Federal Constitutional COURTS}

Certain aspects of the new special constitutional courts are themselves, surely constitutional. Congress has broad power to regulate the jurisdiction of the lower federal courts, and of the appellate jurisdiction of the Supreme Court. ${ }^{77}$ Replacing the usual three-step process for constitutional litigation with a different two-step process is well within Congress' discretion. More questionable but probably still valid are the provisions that instruct the federal courts to decide the constitutional challenges in an expeditious manner. One branch of government telling another how to conduct its business raises separation of powers concerns. But most of the special review provisions do not specify precise time periods within which federal courts must act, and the language seems to be merely a recommendation. ${ }^{78}$ On that understanding, the expediting language does not raise serious constitutional concerns, ${ }^{79}$ and the Supreme Court seems little trou-

Rep. Lott). On the Communications Decency Act, supra note 57, see 142 CONG REC. H1166 (1996) (statement of Rep. Berman). On the Line Item Veto, supra note 59, see Devins, supra note 12, at 443 \& n. 39 (discussing constitutional doubts strenuously raised by Sen. Byrd); Panas, supra note 12, at 170-71 (same).

75 For example, on the Flag Protection Act, supra note 61, see 135 CONG. REC. S23161 (daily ed. Oct. 4, 1989) (statement of Sen. Kohl) ("I am not happy with expedited reviewbecause it means that the Supreme Court will decide an important issue with no factual context outside of a single case."); on the census reform law, supra note 60, see 143 CONG. REC. H8227 (1997) (statement of Rep. Frank) (stating that the expedited review provision improperly asks the Supreme Court to render an advisory opinion).

76 For example, on the Flag Protection Act, supra note 61, see 135 CONG. REC. S23137 (Oct. 4 , 1989) (statement of Sen. Grassley) ("Is the issue important enough to warrant special treatment? Then, I suppose, one may argue that the Congress should seriously consider granting expedited review to cases arising from other worthy contexts such as civil rights, abortion, religious liberty, death penalty.").

77 FALLON ET AL., supra note 13, at 274-306.

78 Ryan, supra note 12, at 802-804

79 See id. at 799-810 (discussing constitutional considerations with regard to express and precise statutory time limits); Panas, supra note 12, at 162-63 (discussing the constitutionality of expediting mandates). 
bled when it acknowledges in opinions that it is expediting treatment of a particular case..$^{80}$

More problematic are other aspects of the special review provisions. Granting members of Congress standing to bring a constitutional challenge is, at least on its face, of doubtful validity. This was made clear in Raines $v$. Byrd $^{81}$ in where the Court considered the special review provision of the Line Item Veto Act. As permitted by the Act, members of Congress, in their individual capacity, brought the suit, and the Court held that they lacked standing. ${ }^{82}$ Lower courts had long struggled with the issue of whether members of Congress possessed standing to challenge the validity of statutes or other governmental action, simply by virtue of their status as legislators, and the Court had itself not been clear on the issue. ${ }^{83}$ The Court in Raines did not purport to definitively resolve the issue, but it did hold that the plaintiffs lacked an injury necessary to satisfy standing. The President had not yet exercised a veto under the Act, so the law at that stage did not affect their votes on appropriation bills, or the lawmaking process in general. ${ }^{84}$ Raines thus cast great doubt on an unqualified right of Congress to statutorily grant standing to its own members simply by virtue of their holding office. ${ }^{85}$ Instead, the Court seemed to permit such standing in those narrower instances where legislative votes had been nullified in some way by the subsequent governmental action which lawmakers were now challenging. ${ }^{86}$

80 E.g., Clinton v. City of New York, 524 U.S. 417, 421 (1998) ("In obedience to the statutory direction to allow a direct, expedited appeal to this Court ... we promptly noted probable jurisdiction and expedited review ...."); Raines v. Byrd, 521 U.S. 811, 817-18 (1997) ("We established an expedited briefing schedule ....").

$81 \quad 521$ U.S. 811 (1997).

82 Id. at $814-18$

83 For an overview, see FALLON ET AL., supra note 13, at 122-23.

84 Raines, 521 U.S. at 824-28 (holding that precedent and "historical practice" work against the appellees in this case).

85 See FALlon ET AL., supra note 13, at 123; Panas, supra note 12, at 159 (explaining the holding of Raines with regard to congressional standing).

86 See Raines, 521 U.S. at 824 (comparing this case to Coleman v. Miller, 307 U.S. 433, 437 (1939), which found that senators did have standing to challenge the bill at issue). The Court's recent decision in United States v. Windsor, 113 S. Ct. 2675 (2013), offered little clarification of this issue. There the President had declined to defend $\S 3$ of the Defense of Marriage Act (DOMA), codified at 1 U.S.C. $\$ 7$, against a constitutional challenge brought by a private party, but still enforced the law. Windsor, $113 \mathrm{~S}$. Ct. at 2683-84. The Bipartisan Legal Advisory Group (BLAG) of the House of Representatives voted to intervene to defend the constitutionality of the statute. $I d$. at 2684 . The majority of the Court held that the United States had standing to pursue the appeal, and did not directly address whether BLAG had standing. Id. at 2684-89. The majority did not mention Raines, but it was discussed by two of the dissenting opinions. Justice Scalia argued that the reasoning, if not the holding, of Raines suggests there was no standing over this dispute be- 
As, if not more, interesting and important than these constitutional questions are institutional ones. Are the professed reasons for special constitutional courts-speed and resolving uncertain constitutional questions-well-served by the provisions? What about the majority of federal statutes that do not have such provisions? Do the provisions, including the added symbolism of three judges sitting at the trial level, best serve the institutional responsibilities of Congress, and of federal courts in general, and the Supreme Court in particular, adjudicating the constitutionality of federal statutes? These questions are explored in the balance of this Part. I conclude that while these provisions do not deserve the sharp criticism of some commentators, they are nonetheless on balance largely unnecessary, and in some ways can be counterproductive, and should not be enacted by Congress.

\section{A. Institutional Responsibilities of Congress}

\section{Congressional Delegation to the Courts}

Recent scholarship has identified a principal defect of special constitutional court provisions. They are evidence, critics argue, that Congress in recent decades has not discharged its historic responsibility of taking seriously its obligation to carefully consider the constitutionality of statutes it passes. One prominent critic, Neal Devins, contends that recently, Congress is often "indifferent" to the constitutionality of statutes it passes, or "treats the Constitution as the exclusive province of the Supreme Court ...." ${ }^{\not 7}$ Special review provisions, he continues, "delegate Congress's power to interpret the Constitution to the Supreme Court," and Congress thereby "signals the Court

tween the legislative and executive branches on the constitutionality of DOMA. Id. at 2703 n.3, 2704 (Scalia, J., dissenting). Justice Alito, in contrast, allowed that whether BLAG had standing was a "difficult question," $i d$. at 2712 (Alito, J., dissenting), but that Raines did not prevent standing, for two reasons. That case, he argued, dealt with individual members of Congress, as opposed to one of the legislative branches acting collectively, and they "were not the pivotal figures whose votes would have caused the Act [in question in Raines] to fail absent some challenged action." Id. at 2714. It bears emphasis that DOMA had no special review provision, much less any language authorizing Congress as a whole or any individual members to sue to challenge the constitutionality of the law. For discussions of standing by Congress and its members in light of Windsor, see Tara Leigh Grove \& Neal Devins, Congress's (Limited) Power to Represent Itself in Court, 99 CORNELl L. Rev. 571 (2014); Tara Leigh Grove, Standing Outside of Article III, 162 U. PA. L. REV. 1311 (2014).

87 Devins, supra note 12, at 442. 
that it has little institutional stake in constitutional matters." ${ }^{\prime 8}$ Other critics argue that some members of Congress may enthusiastically embrace the delegation evidenced by special review provisions, as it "enable[s] skeptical legislators to hold their noses and vote for popular bills that they opposed on constitutional or even partisan grounds." $" 89$

Devins does not rely merely on anecdotal evidence to support these charges, but rather has extensively documented the seeming indifference of Congress in recent decades to constitutional issues. In a recent study of congressional hearings from 1970 to 2010, he demonstrated that hearings on constitutional issues had fallen in both chambers of Congress (principally in the respective judiciary committees) since $1990 .^{90}$ He attributed the decline largely to increased party polarization, the weakening of committee influence, and an increase in posturing by members of Congress. ${ }^{91}$ More recently, Devins argued that Congress' deliberation over the Affordable Care Act was a case study of this phenomenon, as "congressional committees paid virtually no attention to constitutional questions [about the Act] in hearings or committee reports." ${ }^{92}$

These criticisms of the special constitutional review provisions are not without relevance or force, but I think they belie a more complicated story of their passage by Congress and effect on the courts. Consider the Affordable Care Act. Despite apparent congressional indifference to constitutional issues before its passage, there was no special review provision in the law and, so far as I can tell, there was no serious discussion of adding such a provision. ${ }^{93}$ This suggests that

$88 I d$. at 442-43. Devins gave the enactment of the Line Item Veto Act as an example, $i d$. at 443-44, and added that " $\mathrm{t}]$ he Justices almost always invalidate congressional statutes that contain expedited review provisions." Id. at 444.

89 Jamal Greene, Giving the Constitution to the Courts: Political Foundations of Judicial Supremacy, 117 YALE L.J. 886, 897 (2008). The author gave congressional passage of the BCRA as an example. Id. See also Panas, supra note 12, at 170-72 (making arguments similar to Devins and Greene).

90 Neal Devins, Party Polarization and Congressional Committee Consideration of Constitutional Questions, 105 Nw. U. L. REv. 737, 741-53 (2011) (summarizing findings).

91 Id. at 782-83.

92 Neal Devins, Why Congress Did Not Think About the Constitution When Enacting the Affordable Care Act, 106 Nw. U. L. Rev. ColloQuy 261, 270 (2012).

93 The issue goes unmentioned in Devins, $i d$., and in other sources discussing the legislative history of, and constitutional doubts (mainly under the Commerce Clause) raised inside and outside of Congress during debate over, the ACA. See, e.g., ANDREW Koppelman, The TOugh Luck Constitution and the Assault on Health Care Reform 72-90 (2013) (discussing "the constitutional limits that the ACA supposedly transgressed" and arguing that "scholars and judges worked hard to massage and improve them, but they never succeeded in answering obvious difficulties"). On the other hand, to the extent that the 
the creation story of the special review provisions is a more complicated one and not entirely dependent on justifiable criticisms of the lack of congressional deliberations on the constitutionality of proposed statutes. A richer and more complicated narrative would not only include the presence or absence of such constitutional discourse in the legislature, but also such related factors as rational actions by Congress to advance policy goals, ordinary deal-making when statutes are passed, and interest group activity, among other things. ${ }^{94}$

\section{Congressional Cooperation with the Courts}

It is one thing when Congress passes a statute with no, or virtually no, discussion of its constitutionality, much less of any special judicial review provision it may have (or no discussion of whether such a provision is appropriate, for the many statutes that do not have them). But there was some seemingly genuine discussion of constitutional issues in other statutes, if mainly on the floor of Congress before a final vote, with the Line Item Veto Act being a good example. ${ }^{95}$ Congress undeniably can send signals to the federal courts when it enacts statutes and in other ways. ${ }^{96}$ Rather than evidence of abdication of responsibilities, the presence of a special review provision can be conceptualized as a signal to the federal courts that the matter is a serious one that ought to be undertaken with sufficient gravity by the third branch of government. That is, it can be viewed as a heightened awareness by Congress that there are serious constitutional is-

supporters of the ACA took seriously the constitutional objections, perhaps they did not want any likely legal challenge to be facilitated or accelerated by a special review provision.

94 See BAum, supra note 16, at 42-46 (discussing these and other reasons for creation of specialized courts in general); CHARLes R. SHIPAN, Designing Judicial ReVIEW: INTEREST Groups, CONGRESS, AND COMMUNiCATIONS POLICY 15-33 (1997) (attributing design of judicial review provisions in part to interest groups affected by the statute in question); Alon Cohen, Independent Judicial Review: A Blessing in Disguise, 37 INT'L REv. L. \& ECON. 209, 209-10 (2014) (arguing that providing for independent judicial review may be a device to enable politicians to destabilize a law they oppose).

$95 \quad$ See supra note 74.

96 See, e.g., Tom S. Clark, The Separation of Powers, Court Curbing, and Judicial Legitimacy, 53 AM. J. POL. SCI. 971, 971 (2009) (examining how Court-curbing legislation proposed in Congress between 1877 and 2006 influenced the rate of the Supreme Court striking down federal statutes as unconstitutional); Amanda Frost, Congress in Court, 59 UCLA L. REv. 914, 919 (2012) (discussing how Congress can exert influence over the judiciary); Eugenia Froedge Toma, Congressional Influence and the Supreme Court: The Budget as a Signaling Device, 20 J. LEGAL STUD. 131, 131 (1991) (discussing how Congress uses budgets to signal intent). 
sues at play, coupled with an arguably genuine concern that certain factors make a prompt resolution of the issue appropriate.

The modern special review provisions can be usefully compared to the expansion of the jurisdiction of the three-judge district court in 1937 to include constitutional challenges to federal statutes. ${ }^{97}$ It might seem odd that Congress at that time would put federal statutes on a speedier path toward review by a Supreme Court which had shown little hesitation to strike down New Deal legislation. Several factors explain the incongruity. The three-judge court provision was mainly intended to forestall the actions of district judges acting alone, some of whom (at least in the minds of Congress) had issued opinions exhibiting overt hostility toward New Deal statutes. ${ }^{98}$ More broadly, the amount of sustained attention Congress gave to the constitutional basis of early New Deal legislation seems limited. ${ }^{99}$ Rather than reflecting a clear congressional judgment on constitutional issues, the 1937 expansion was primarily intended as a yoke on some federal judges in the lower courts perceived to be hostile to the New Deal. Thus, the 1937 expansion was not predicated on constitutional doubts expressed in Congress, but rather on a general belief in the validity of that legislation and to avoid the binding (if temporary) effect of the decisions of single district judges. ${ }^{100}$ Contrary to Justice

97 See supra notes 25-31 and accompanying text.

98 Frankfurter \& Fisher, supra note 30, at 617-18 ("[T] he inevitable irritation of Congress at the free-handed way in which single judges throughout the country enjoined the enforcement of some of the most vital measures ever enacted, made inevitable the requirement of Section 3 for a court of three judges to set aside the will of Congress.”).

99 See Jeff Shesol, Supreme Power: Franklin Roosevelt vs. The Supreme Court 43 (2010) (discussing the fact that legislation during this period was not given much attention). While the causes and consequences of the 1937 Court-packing plan remains the subject of scholarly debate, see, e.g., Laura Kalman, The Constitution, the Supreme Court, and the New Deal, 110 AM. HiST. REV. 1052, 1052 (2005) (discussing cases from this era), there is common consensus that much early New Deal legislation was hurriedly drafted, with little consideration to the constitutional basis for the laws. See, e.g., Barry Cushman, The Hughes Court and Constitutional Consultation, 23 J. SuP. CT. HIST. 79, 81 (1998) (discussing Frazier-Lemke Farm Debt Relief Act of 1934 and noting that some believed it was rushed into legislation); Neal Devins, Government Lawyers and the New Deal, 96 CoLUM. L. REV. 237, 244, 251 (1996) (reviewing William E. Leuchtenburg, THE Supreme Court Reborn: The Constitutional Revolution in the Age of RoOsevelt (1995) and giving examples of legislation from this period that was quickly and poorly drafted). By contrast, Congressional attention to that issue became greater once the Court began striking down legislation passed early in the New Deal. See, e.g., DonAld G. MORGAN, Congress AND THE CONSTITUtION: A STUDY OF RESPONSIBILITY 163-83 (1966) (discussing congressional consideration and discussion of constitutional basis for the Bituminous Coal Conservation Act of 1935); Cushman, supra note 95, at 81-90 (discussing the drafting of various laws during the second New Deal).

100 While congressional support for FDR's court-packing plan eroded in the spring and summer of 1937, it does not follow that majorities in Congress were expressing doubts 
Scalia and Professor Garner, then, enactment of a standing or particular special review provision is not inexorably evidence of constitutional doubts in Congress.

The seriousness of purpose can also be reflected by the other typical features of special review provisions. Permitting members of Congress themselves to initiate or to intervene in the anticipated litigation highlights the equal and complimentary footing one branch has with the other. For the past several decades the appellate judges in the District of Columbia Circuit have often been regarded in many quarters as the second-most prestigious and important federal court. This is due to the perceived high quality of the federal judges serving in the District, the appeals of important agency and other administrative actions exclusively vested in the District, and the fact that many Supreme Court Justices have previously served on the D.C. Circuit. ${ }^{101}$ Placing exclusive venue of special constitutional litigation in the Circuit (recall that three-judge district courts have at least one circuit judge) might be said to underline the importance Congress wishes to give these proceedings. All these factors can be said to resemble a dialogue between Congress and the Court, which scholars have advanced as descriptive of and normatively preferable to the relationship between Congress and the Supreme Court. ${ }^{102}$

about the constitutionality of New Deal legislation. Also, passage of the 1937 expansion took place on August 24 of that year, after the plan had been abandoned and the controversy subsided. Indeed, by that point the Court had begun upholding New Deal legislation, and the expansion makes even more sense as an effort to rein in possibly hostile district judges sitting alone and to expedite appeals to a now more friendly Supreme Court. See SHESOL, supra note 99, at 516; Frankfurter \& Fisher, supra note 30, at 610 (observing the fear "[t]hat the fate of acts of Congress should depend, even temporarily, upon the view of a single judge"). Cf. Michael P. Foradas, Comment, Section 1252: A Jurisdictional Dinosaur, 75 Nw. U. L. REv. 175, 177-78 (1980) (discussing relationship or lack thereof between the Court-packing plan and the expansion of the three-judge district court).

101 See Christopher P. Banks, Judicial Politics in the D.C. Circuit Court 7-19 (1999) (discussing the rise of the DC Circuit); LEE EPSTEIN, WiLLIAM M. LANDES \& RICHARD A. Posner, The Behavior of Federal Judges: A Theoretical and EMPIRICAL Study of RATIONAL CHOICE 351 (2013) (pointing out that DC Circuit judges are disproportionately considered for the Supreme Court); Eric M. Fraser et al., The Jurisdiction of the D.C. Circuit, 23 Cornell J.L. \& PUB. POL'Y 131, 131 (2013) (discussing the D.C. Circuit's unique reputation); John G. Roberts, Jr., What Makes the D.C. Circuit Different? A Historical View, 92 VA. L. Rev. 375, 375 (2006) (discussing the differences between the D.C. Circuit and other circuit courts); Michael E. Solimine, Judicial Stratification and the Reputations of the United States Courts of Appeals, 32 FLA. ST. U. L. REV. 1331, 1332 (2005) (exploring the reputations of some courts of appeals, including the D.C. Circuit).

102 See, e.g., Barry Friedman, A Different Dialogue: The Supreme Court, Congress and Federal Jurisdiction, 85 Nw. U. L. REv. 1, 2-3 (1990) (offering "a view of federal jurisdiction in which the boundaries of authority are far less clear than commentary suggests, and in which the contours of federal jurisdiction are resolved as the result of an interactive process be ween Congress and the Court on the appropriate uses and bounds of the federal judicial 
At least some of the special review provisions might be viewed, again, not as abdication of congressional responsibilities, but rather as the product of the rather ordinary process of the passage of most statutes and the compromise and deal-making process that often attends that passage. The provisions in recent election law statutes provide a good example. There is some evidence that the special judicial review provisions of the 1974 amendments to FECA were due to an explicit or implicit compromise between the proponents and opponents of the law. Constitutional questions had been discussed in the legislative debates, and there is some suggestion that both supporters and opponents anticipated a constitutional challenge, and each side was betting that courts would uphold their views. ${ }^{103}$ The regular cycle of elections and the planning for campaigns elevates the need for rapidity and resolution of constitutional challenges. ${ }^{104}$ Perhaps they also thought that the federal judges in the District, not beholden to the political and legal culture of particular states, might be more sophisticated about politics and more likely to uphold the law. ${ }^{105}$ On the other hand, the language permitting members of Congress to sue arguably removed doubts about the standing of legislators, and seemingly made a constitutional attack easier. Similar reasons might account for the special review provisions of the BCRA. ${ }^{106}$

power"); Devins \& Fitts, supra note 12, at 359 ("Just as the Court informs Congress about the meaning of the Constitution, Congress too should educate the Court."). Since the 1990s, increasing polarization between the parties in Congress, and apparent conflict at times between Congress as a whole and the Court, has led some observers to conclude that the dialogue is moribund. See, e.g., Richard L. Hasen, End of the Dialogue? Political Polarization, the Supreme Court, and Congress, 86 S. CAL. L. REv. 205, 209 (2013) ("Although political polarization has benefitted the Supreme Court's power relative to Congress in the short term, the longer-term power relations are more uncertain."). But see Matthew R. Christiansen \& William N. Eskridge, Jr., Congressional Overrides of Supreme Court Statutory Interpretation Decisions, 1967-2011, 92 TEX. L. REv. 1317, 1318-25 (2014) (arguing that overrides of statutory overrides are more prevalent than sometimes recognized and may be so in the future).

103 See Solimine, Institutional, supra note 47, at 774-75 ("Yet, the very existence of the provision suggests that (some of) the drafters and their supporters wished to facilitate a court challenge."); Rebecca Curry, Making Law with Lawsuits: Understanding Judicial Review in Campaign Finance Policy, 46 Suffolk U. L. REv. 389, 419-27 (2013) ("Among a certain faction of FECA's authors, there is ample evidence of an attempt to kill the law with constitutionalism.").

104 See Wagner v. FEC, 717 F.3d 1007, 1014 (D.C. Cir. 2013) (per curiam) (discussing this need in light of the repetition of elections).

105 See Solimine, Institutional, supra note 47, at 773 ("Perhaps the supporters thought a federal district court in the District of Columbia would, all things being equal, possess more legal acumen and political sophistication than federal judges elsewhere ....").

106 See Douglas, supra note 70, at 468-69; Solimine, Institutional, supra note 47, at 773-75 (noting the "various reasons" that "special review provisions may have been an implicit 
Some of the other special review provisions discussed earlier might also be characterized as the product of legislative compromise.

I am not suggesting that these alternative rationales are preferable to the more cynical ones advanced by Justice Scalia and other critics of special review provisions. Rather, my point is that a fuller appreciation of the reasons driving congressional behavior suggests that the special review provisions are not devoid of some arguably sound rationales. Nonetheless, I believe these provisions do not reflect sound policy. The principal reasons I reach this conclusion are found in the next Subsection of this Part.

\section{B. Institutional Effects on the Courts}

As noted above, ${ }^{107}$ the demise of the standing three-judge court district to adjudicate constitutional challenges to federal statutes was largely due to opposition from the Supreme Court and its allies. The opposition was based on the asserted deleterious effects on the operation of the federal courts. Critics argued that it was administratively burdensome to assemble such courts, that direct appeals to the Supreme Court burdened the usual discretionary docket control, and that ultimately the special process was unnecessary. ${ }^{108}$ To be sure, the special review provisions addressed in this Article do not duplicate the standing court repealed in 1976. The newer provisions are attached to a relatively few specific statutes. Nonetheless, they share some of the same characteristics as the three-judge district court as it existed before the 1976 repeal, and often have some aspects (e.g., exclusive jurisdiction in the District Court for the District of Columbia) not found in the prior court. ${ }^{109}$ The demise of the older court, and the purported benefits of the usual way of litigating challenges to most federal statutes, provide useful markers to examine the effects of the new constitutional review provisions.

\section{Specialization and Percolation}

Recall that the repealed three-judge district court for challenging federal statutes was an amendment to the then-existing court used to adjudicate challenges to state statutes. Many of the criticisms ultimately launched against the latter applied with equal force to the

part of the legislative deal that culminated in passage of the BCRA"); Panas, supra note 12, at 164 (referencing FECA). 
former. Consider vesting a constitutional challenge to a federal statute in a specialized court, as opposed to other issues, such as cases raising interpretation, application or enforcement of the statute. Specialized courts for what are regarded as particularly unique or complicated areas of law (e.g., patent or taxes) may be beneficial. ${ }^{110}$ But constitutional issues, as such, do not seem to fall into that category. While the statutes themselves may sometimes be complicated, the constitutional provisions at issue are not. Indeed, the problem is often that the constitutional language is open-ended and raises issues and requires decision-making that resembles the overtly political and policy judgments of the non-judicial branches of government. ${ }^{111}$ This is of course not to say that constitutional litigation is not complex and complicated compared to other cases typically litigated in federal courts. Nonetheless, whatever else might be said about the resolution of constitutional cases, not the least of which is the debate over interpretative methodologies to cabin judicial (and particularly Supreme Court) discretion, there seems no strong reason to assemble a special group of judges to make such decisions at the trial level.

All of the new provisions have a direct appeal of the trial court decision to the Supreme Court, different from the ordinary discretionary certiorari jurisdiction. ${ }^{112}$ A direct appeal, which ostensibly must be

110 Specialized courts in the federal system have not been without controversy, as not having served their intended goals. For example, the jury is still out on the establishment of the Federal Circuit in 1982 as the one appellate court for (among other things) patent litigation. Some scholars argue that the Federal Circuit has not delivered on its promise to provide uniformity and stability in patent law. Circuit splits on patent issues have disappeared, but the Supreme Court has increasingly taken an active role in reviewing, and sometimes reversing, the patent decisions of the Federal Circuit. For overviews of the debate, see BAUM, supra note 16, at 181-86; Rochelle C. Dreyfuss, Percolation, Uniformity, and Coherent Adjudication: The Federal Circuit Experience, 66 SMU L. REv. 505 (2013); John M. Golden, The Federal Circuit and the D.C. Circuit: Comparative Trials of Two Semi-Specialized Courts, 78 GeO. WASH. L. REv. 553 (2010); Paul R. Gugliuzza, The Federal Circuit as a Federal Court, 54 WM. \& MARY L. REv. 1791, 1802-03 (2013). Some have argued that returning patent issues to circuit percolation, or even to state courts, might be advisable. See, e.g., Paul R. Gugliuzza, Patent Law Federalism, 2014 WIS. L. REv. 11, 16 (challenging "the assumptions that legal uniformity and patent-specific expertise justify excluding state courts from hearing patent cases"); Craig Allen Nard \& John F. Duffy, Rethinking Patent Law's Uniformity Principle, 101 Nw. U. L. REv. 1619, 1622 (2007) (finding fault in "the Federal Circuit's exclusive subject matter jurisdiction over patent cases").

111 See Richard A. Posner, A Political Court, 119 HARV. L. Rev. 32, 39-40 (2005) (exploring whether courts should be considered political bodies when deciding constitutional questions).

112 Congress acted twice to repeal the former direct appeal: in 1976 to eliminate the threejudge district court to hear constitutional challenges to federal statutes, which also eliminated the direct appeal associated with those courts, and in 1988 to eliminate a direct appeal from any district court decision holding a federal statute unconstitutional. See supra Part II. 
decided by the Court, deprives the Court of the benefit of a decision by a court of appeals, but also of the views of other federal courts across the country which may have ruled on the issue. In a direct appeal, only three judges (and sometimes only one, depending on the statute) will have considered the matter, while in ordinary litigation and appeals potentially a score or more of federal judges may have done so before it reaches the Court. The phenomenon of the percolation of issues in the lower courts, before Supreme Court review, has generated a large commentary. Proponents of percolation, on ${ }^{113}$ and off $^{114}$ the Court, argue that the Court (and the federal court system as a whole) benefits from the potential diversity of views generated by different jurists in different courts rulings on an issue. Such percolation may aid the Court in deciding whether to review an issue at all, in reaching a more informed final decision once it decides to resolve a split in authority, and by encouraging lower court judges to take their jobs more seriously, knowing that their work may aid in developing the law. Proponents argue that the benefits of percolation are particularly important in constitutional cases, since there Congress has fewer options to respond, as opposed to cases involving what Congress sees as an errant decision of statutory interpretation. ${ }^{115}$ Proponents are thus particularly skeptical of most specialized courts, ${ }^{116}$ and presumably would be skeptical of the new specialized review provisions.

Critics of percolation are found on ${ }^{117}$ and off ${ }^{118}$ the Court as well. They contend that the putative benefits are overstated. Some point

113 E.g., McCray v. New York, 461 U.S. 961, 963 (1983) ("In my [Justice Stevens] judgment it is a sound exercise of discretion for the Court to allow the various States to serve as laboratories in which the issue receives further study before it is addressed by this Court").

114 E.g., PosNer, supra note 17, at 263-64; Amanda Frost, Overvaluing Uniformity, 94 VA. L. REV. 1567, 1573 (2008) (questioning whether judicial uniformity is a valuable goal); Doni Gewirtzman, Lower Court Constitutionalism: Circuit Court Discretion in a Complex Adaptive System, 61 AM. U. L. REV. 457, 481-94 (2012) (suggesting "the need for a new approach to lower court constitutionalism, one that recognizes the full set of normative values advanced by an interpretive system that empowers lower courts to make choices about constitutional meaning").

115 E.g., Daniel J. Meador, A Challenge to Judicial Architecture: Modifying the Regional Design of the U.S. Courts of Appeals, 56 U. CHI. L. REv. 603, 633-34 (1989) (arguing that percolation "has its greatest force in relation to constitutional questions").

116 E.g., Revesz, supra note 13, at 1155-59 (analyzing "a set of arguments that generally counsel against the creation of specialized courts that are not subject to review in the generalist courts of appeals").

117 E.g., Justice William H. Rehnquist, The Changing Role of the Supreme Court, 14 FLA. ST. U. L. REV. 1, 11 (1986) ("And to go further and suggest that it is actually desirable to allow important questions of federal law to 'percolate' in the lower courts for a few years before the Supreme Court takes them on seems to me a very strange suggestion; at best it is making a virtue of necessity."). 
out that delaying a definitive resolution while an issue plays out in the lower courts is unfair to the litigant who happened to be before the court that ruled the incorrect way. ${ }^{119}$ Others argue that percolation perpetuates uncertainty and non-uniformity in the law, especially problematic when it comes to the interpretation of constitutional rights which ostensibly apply equally across the nation. ${ }^{120}$ Still others contend that the Supreme Court rarely internalizes the benefits of percolation. While the Court may refer to a circuit split in an opinion mentioning why it granted certiorari, it appears, critics argue, that the Court rarely relies on the analysis developed by lower courts when fashioning its final decision. ${ }^{121}$ The critics would presumably be less skeptical of a special review provision which bypasses any percolation in the lower courts.

How do these critiques apply to the special review statutes? Does the Court resolve appeals from cases not involving such provisions in a better or more informed way than cases on direct appeal? It is difficult to say, since the quality of a Supreme Court decision is much in the eye of a beholder; objective indicia of opinion quality are notoriously difficult to apply. Doctrinal reliance by the Court on lower court opinions grappling with the merits is one way to measure the

118 E.g., Paul M. Bator, What is Wrong with the Supreme Court?, 51 U. PITT. L. REV. 673, 690 (1990) (arguing that " $[\mathrm{w}]$ hether or not percolation works—and how well it works-are matters of accident"); Wayne A. Logan, Constitutional Cacophony: Federal Circuit Splits and the Fourth Amendment, 65 VAND. L. REV. 1137, 1160-85 (2012) (examining "the difficulties presented by" circuit splits, particularly in the Fourth Circuit).

119 See, e.g., Bator, supra note 118, at 689 (“[W] e must always remember that perpetuating uncertainty and instability during a process of percolation exacts important and painful costs. Of course, law professors and appellate judges do not pay these costs. It is the citizens and firms whose affairs are confounded and prejudiced by uncertainty and instability in the law who pay the price."); Rehnquist, supra note 117, at 11 ("It is of little solace to the litigant who lost years ago in a court of appeals decision to learn that his case was part of the 'percolation' process which ultimately allowed the Supreme Court to vindicate his position.").

120 See, e.g., Logan, supra note 118, at 1171-74 (arguing that "[a]llowing such variation is a recipe for public disillusionment over the authoritativeness of national institutions").

121 See, e.g., Bator, supra note 118, at 690 (questioning whether "the Supreme Court Justices and law clerks read" lower court opinions); Evan H. Caminker, Precedent and Prediction: The Forward-Looking Aspects of Inferior Court Decisionmaking, 73 TEX. L. REv. 1, 58-59 (1994) ("I question whether inferior court judgments significantly influence ultimate Supreme Court rulings very often."); Henry J. Friendly, The "Law of the Circuit" and All That: Foreword to the Second Circuit 1970 Term, 46 ST. JOHN's L. REV. 406, 407 (1972) ("If a case involves questions of federal law of such importance as to be reviewed by the Supreme Court, the views of the court of appeals count, and should count, for little."). The Court has also been unclear and inconsistent about what deferential weight, if any, it gives to the numbers of circuits on each side of a circuit split. For a discussion of this, see AaronAndrew P. Bruhl, Following Lower-Court Precedent, 81 U. CHI. L. REv. 851, 853-856 (2014) (questioning the weight that should be given to unbalanced circuit decisions). 
efficacy of percolation or its absence. Some empirical studies suggest that this rarely occurs in the Supreme Court. ${ }^{122}$ For a very small recent sample, contrast NFIB v. Sebelius and Citizens United. Recall that there was a circuit split in the former case. There was some modest reference in the majority opinion by Chief Justice John Roberts, ${ }^{123}$ and in the concurring and dissenting opinion by Justice Ruth Ginsburg, to the lower court opinions to support their analyses. ${ }^{124}$ By contrast, none of the opinions in Citizens United relied in any substantive way on the analysis of the lower court opinion, save for a few fleeting references to the facts of or the record in the case. ${ }^{125}$

Definitively drawing the conclusion that the Court rarely relies on lower court opinions in its analysis when there are circuit splits, and rarer still when it decides cases on direct appeal, awaits further empirical study. What can be said at this point is that there seem very few occasions in direct appeals, as compared to circuit splits, for the Court to gain the advantage of discerning how more than one lower court considered and resolved an issue. While it is true that the Court rarely expressly acknowledges that advantage, even in cases with circuit splits, some empirical research indicates that the Court takes into account the presence or absence of a circuit split when de-

122 E.g., Logan, supra note 118, at 1167-68 (publishing study of 138 Fourth Amendment decisions in the Supreme Court from 1981 to 2010 Terms, which demonstrates the Court rarely mentioned the existence of a circuit split and rarely utilized circuit court opinions to develop the doctrine resolving the case).

123 Nat'l Fed'n of Indep. Bus. v. Sebelius, 132 S. Ct. 2566, 2583 (2012) (citing and abrogating Thomas More Law Ctr. v. Obama, , 551 (6th Cir. 2011)); id. at 2588 (citing Seven-Sky v. Holder, 661 F.3d 1, 14-15 (D.C. Cir. 2011)).

$124 I d$. at 2620-22 (Ginsburg, J., concurring in part and dissenting in part) (citing Thomas More, 651 F.3d at 561, 565 (Sutton, J., concurring in part) and Seven-Sky, 661 F.3d at 16). The joint opinion of four Justices dissenting did not cite a lower court opinion.

125 See Citizens United v. FEC, 558 U.S. 310, 322-23 (2010) (citations to lower court opinion for procedural history purposes). Perhaps a better comparison would be to the precursor to Citizens United, McConnell v. FEC, 540 U.S. 93 (2003). The former case was mainly considering whether to reverse the latter, and the lower court understandably did not consider that issue. In contrast, in the latter case the BCRA had just been passed, and a host of new factual and legal issues was confronting both the three-judge panel and the Supreme Court. The Court in McConnell made frequent reference to the lower court decision regarding the record in the case and the factual findings made below. E.g., id. at 124-29, 146-51, 175-76; id. at 301-04 (Kennedy, J., dissenting). At several points the Court also arguably adopted or relied in part on the legal analysis of the district court, as evidenced by citations to the lower court opinions. E.g., id. at 167-68, 193, 197 (discussing issues that were undisputed or agreed upon by all the lower court judges, or quoting the lower court extensively). In its most recent BCRA decision, the Court made only brief reference to the analysis of the court below. McCutcheon v. FEC, 134 S. Ct. 1434, 1455 (2014) (describing this analysis in only a few sentences). Cf. id. at 1481-84 (Breyer, J., dissenting) (providing extensive quotations from district court opinion in McConnell in Appendix A to the opinion). 
ciding whether to review a case, and if so, resolving it on the merits. In the latter circumstance, the Court will often (whether it acknowledges it or not) take the side of the majority of the circuits in a split. ${ }^{126}$ The existence of a circuit split may also inform the selection of cases for review, ${ }^{127}$ and perhaps even the drafting of an opinion, ${ }^{128}$ even when not expressly mentioned in the opinion. These benefits, modest though they may be when there are circuit splits, seem practically nonexistent when there are direct appeals. ${ }^{129}$

A related (if imperfect) way to measure the quality of lower court opinions is the rate of reversal on appeal. ${ }^{130}$ On that score, the feder-

126 See Stefanie A. Lindquist \& David E. Klein, The Influence of Jurisprudential Considerations on Supreme Court Decisionmaking: A Study of Conflict Cases, 40 LAW \& SOC'Y REv. 135, 135 (2006) (studying 338 Supreme Court decisions from the 1985-1995 Terms, where certiorari was granted to resolve a circuit split, and showing that the Court was more likely to adopt the position of a majority of the circuits); see also Tom S. Clark \& Jonathan P. Kastellec, The Supreme Court and Percolation in the Lower Courts: An Optimal Stopping Model, $75 \mathrm{~J}$. POL. 150, 150 (2013) (arguing the Court faces a strategic tradeoff between allowing a conflict to continue to gain information, and ending the conflict by grating review, and in study using data from Lindquist \& Klein article found that review is typically granted only after a conflict persists).

127 Gewirtzman, supra note 114, at 493-94.

128 Cf. Pamela C. Corley, Paul M. Collins Jr. \& Bryan Calvin, Lower Court Influence on U.S. Supreme Court Opinion Content, 73 J. PoL. 31, 31 (2011) (publishing study of Supreme Court majority opinions in 2002-2004 Terms, using plagiarism software, that showed the Court systematically incorporated language from lower court opinions).

129 Depending on the length and number of opinions in the lower court, and particularly if it is a three-judge district court, there might be some similarities to full percolation. For example, in McConnell all three judges on the lower court issued their own lengthy opinions, in addition to the per curiam opinion of that court, and the three separate opinions take up over 800 pages in the official reports. See McConnell v. FEC, 251 F. Supp. 2d 176919 (D.D.C. 2003); see also Solimine, supra note 47, at 776-77 (discussing these opinions). But this is an exception to the ordinary opinion generation that has occurred in cases with special review provisions. Cf. Ryan Stephenson, Note, Federal Circuit Case Selection at the Supreme Court: An Empirical Analysis, 102 GEO. L.J. 271, 286-87 (2013) (suggesting that for case selection by the Supreme Court, dissents in the Federal Circuit are substitutes for circuit splits that ordinarily occur in non-patent cases).

On the other hand, a procedural quirk of three-judge district court litigation, with direct review, can deprive that litigation of even modest information to the Court about circuit court opinion on issues. There is not a circuit split as such, but rather a split of authority among three-judge district courts about how much precedential weight, if any, such courts should give to the opinions of the circuits in which they sit. Since three-judge district court opinions are not reviewed by the court of appeals, some argue that it is inappropriate for the former court to be bound by the decisions of the latter. The contrasting, and apparently majority view seems to be that such courts should give such weight to circuit authority, although most courts seem to do it without extensive discussion of the issue. For discussion, compare Parker v. Ohio, 263 F. Supp. 2d 1100, 1105 (S.D. Ohio 2003) (three-judge court) (stating that it is bound by circuit decisions) with $i d$. at 1112 n.3 (Gwin, J., concurring) (questioning this assumption).

130 See, e.g., Stephen J. Choi et al., What Do Federal District Judges Want? An Analysis of Publications, Citations, and Reversals, 28 J. L. ECON. \& ORG. 518, 519 (2011) (making arguments 
al district court decisions rendered under the special review provisions addressed in this Article do comparatively well. Of the twentytwo lower court decisions appealed to the Supreme Court, fourteen, or $64 \%$, were affirmed by only an opinion or in a summary fashion. ${ }^{131}$ Given that the historic reversal rate of the Supreme Court in all cases is about $50 \%$, this suggests that the specialized trial courts are getting it right more often than not. ${ }^{132}$ On the other hand, the direct appeals mandated by the special review provisions present a skewed sample of cases, unlike the other cases on the Court's docket, which it assembles by way of the discretionary writ of certiorari.

\section{Exclusive Jurisdiction in the District of Columbia Circuit}

Many of the special review provisions vest exclusive jurisdiction of constitutional challenges in a three-judge district court in the District of Columbia, followed by a direct appeal to the Supreme Court. As previously observed, ${ }^{133}$ the federal courts in the District possess jurisdiction beyond the civil and criminal matters that arise from people living and working there. In addition, Congress has vested exclusive or permissible jurisdiction in those district courts and the appellate court over a wide range of challenges to the administrative decisions of the federal government, and of appeals from federal agency decisions. ${ }^{134}$ This is true no matter in what other state or states the underlying controversy arises. The expertise and sophistication of the fed-

about reversal rates based on the types of circuits in which judges sit); Jonathan Remy Nash \& Rafael I. Pardo, An Empirical Investigation into Appellate Structure and the Perceived Quality of Appellate Review, 61 VAND. L. REV. 1745 (2008) (publishing data on "affirmance rates in and citation rates to appellate bankruptcy opinions" and making arguments about the quality of those decisions).

131 The number and percentage of affirmances rises to $15 \%$ and $65 \%$, respectively, if we include one decision that was affirmed in part and reversed in part. If we further exclude one appeal that was dismissed, there are nineteen lower court decisions with an affirmance rate of $79 \%$. Four lower court decisions were reversed or vacated. In these calculations, I exclude one case where certiorari was denied. For the lower court decisions and the disposition (if any) by the Supreme Court that are the bases for these calculations, see supra notes 46-66 \& accompanying text.

132 On the historic reversal in the Supreme Court for all cases, see EPSTEIN, supra note 23, at 729-35 (setting out affirmance and reversal rates of decisions from the U.S. courts of appeals and the U.S. district courts from 1946 to 2009 Terms).

133 See supra note 101 and accompanying text.

134 Many statutes place exclusive review of agency decisions or other matters in the district court or in the D.C. Circuit. Other provisions, e.g., 28 U.S.C. $\$ 1391(\mathrm{e})$, are not exclusive but permit a litigant to sue in, among other places, the place of work of a high agency official, which is typically the District. See Solimine, supra note 101, at 127; Cass R. Sunstein, Participation, Public Law, and Venue Reform, 49 U. CHI. L. Rev. 976, 982-85 (1982) (discussing "[v]enue in [a]dministrative $[\mathrm{r}]$ eview"). 
eral judges serving on these courts in dealing with complex and important legal and policy questions has led the D.C. Circuit to be touted as the second-most important court in the United States. ${ }^{135}$

The District of Columbia Circuit is rightly regarded as being staffed with highly qualified judges who perform good work on difficult and important cases, often in the area of administrative and regulatory law. This specialization does not spill over, however, into constitutional law as such, much less questions regarding the constitutionality of federal statutes. There is no reason federal judges in the District carry more knowledge or insight about such questions as compared to federal judges sitting elsewhere in the United States. The vesting of exclusive jurisdiction in the District over many administrative or regulatory matters may well be efficient and justified, but it is an exception to the general, long-standing notion that the regional dispersion of the federal courts is the better practice. ${ }^{136}$ Placing exclusive jurisdiction in the District carries with it the potential detriments of any specialized court, such as the politicization of the judicial selection process for the court, or the undue influence of a specialized bar or other interest groups. ${ }^{137}$ In recent years, there has been political controversy over the nominations of judges on the D.C. Circuit by both Democratic and Republican presidents, when the Senate was controlled by the other party. Until filibuster rules were controversially changed for such nominations late in 2013, vacancies on the D.C. Circuit had gone unfilled for years. ${ }^{138}$ There has also

135 The D.C. Circuit has replaced the Second Circuit as enjoying this label. For discussion of the switch, see Solimine, supra note 101, at 1332 n.5, 1353-61.

136 See Judicial Conference of the United States, Long Range Plan of the Federal COURTS: As APPROVED BY THE JUdiCiAL CONFERENCE 43 (1995) ("History suggests the value of maintaining regional connections between appellate judges and the trial judges whose decisions they review, and between appellate judges and the litigants who appear in their courts."); POSNER, supra note 17, at 258-59 (supporting regional dispersion of federal appellate courts).

137 See BAUM, supra note 16, at 34-41 (discussing "the effects of specialization on the substance of judicial policy").

138 For overviews of the recent controversy over nominations to the D.C. Circuit, see Carl Hulse, G.O.P. Stirring Feud in Senate On U.S. Judges, N.Y. TIMES, Mar. 9, 2013, at A1; Doug Kendall \& Simon Lazarus, Broken Circuit, 30 ENVTL. F. 36 (2013); Jeremy W. Peters, Senate Vote Curbs Filibuster Power to Stall Nominees, N.Y. Times, Nov. 22, 2013, at A1. Earlier, several Republican members of the Senate Judiciary Committee introduced a bill that would reduce the number of full-time judges on the D.C. Circuit from eleven to eight. Court Efficiency Act of 2013, S. 699, 113th Cong. § 2(b)(1) (2013). Supporters of the bill argued that the reduction was justified by that circuit's comparatively small caseload. Critics argued that it was an effort to prevent President Obama from filling vacancies on that court. Michael D. Shear \& Jeremy Peters, Judicial Picks Set the Stage for a Battle In the Senate, N.Y. Times, June 5, 2013, at A12. That all said, there appears to be less controversy over 
been long-standing, if more muted, controversy over the vesting of jurisdiction in the District over disputes mainly concerning other parts of the United States. ${ }^{139}$

The federal courts in the D.C. Circuit loomed large in the litigation culminating in Shelby County v. Holder ${ }^{140}$ in which the Supreme Court held the current version of the preclearance provision of the Voting Rights Act (VRA) unconstitutional. ${ }^{141}$ That provision required certain jurisdictions to pre-clear election law changes by seeking the approval of either the Department of Justice or of a three-judge district court in the District of Columbia. The legislative history of the latter provision indicates that exclusive venue was placed in the District, due to the fear (at least in 1965, the year of initial passage) that federal judges in the South would not be sympathetic to enforcement of the VRA, and that judges in Washington might eventually build up expertise in and generate uniform law on these matters. ${ }^{142}$ The procedural posture of Shelby County was such that the constitutional attack on the preclearance provision was brought before a single district judge in the District of Columbia, with the usual appellate

the appointment of district judges for the District, who (unlike in other circuits) are rarely elevated to the court of appeals.

139 For discussion, see Thomas O. McGarity, Multi-Party Forum Shopping for Appellate Review of Administrative Action, 129 U. PA. L. REv. 302, 308 (1980) (discussing a dispute over the District of Columbia Circuit's jurisdiction); Edward M. Mullins \& Rima Y. Mullins, You Better Shop Around: Appellate Forum Shopping, 25 LiTigation 32, 35 (1999); Sunstein, supra note 134, at 979 (discussing "venue reform proposals" that would "bar institution of suit in the District of Columbia unless the agency decision under review had a substantial local impact").

140133 S. Ct. 2612 (2013).

141 Specifically, the majority of the Court held unconstitutional the coverage formula, section 4 of the VRA, 42 U.S.C. $\S 1973 \mathrm{~b}$, thus negating use of the preclearance requirements of section 5. 42 U.S.C. § 1973c. Shelby County, 133 S. Ct. at 2648 (Ginsburg, J., dissenting) ("The Court stops any application of $\S 5$ [of the VRA] by holding that $\S 4$ (b)'s coverage formula is unconstitutional.").

142 For discussion of the motivations of the drafters of the preclearance provision in 1965 regarding venue, see Abigail M. Thernstrom, Whose Votes Count? AfFirmative ACTION AND MinORity Voting Rights 16-21 (1987); Chandler Davidson \& Bernard Grofman, The Voting Rights Act and the Second Reconstruction, in QUIET REVOLUTION IN THE South: The Impact OF THE Voting Rights Act, 1965-1990, at 378, 379 (Chadler Davidson \& Bernard Grofman eds., 1994); Gyung-Ho Jeong, Gary J. Miller \& Itai Sened, Closing the Deal: Negotiating Civil Rights Legislation, 103 AM. POL. SCI. REv. 588, 599-601 (2009). Attempts to broaden venue for preclearance actions, beyond just the federal court in the District of Columbia, were rejected in the in the 1970 and 1975 reauthorizations. DAVID J. Garrow, Protest at Selma: Martin Luther King, JR., AND the Voting Rights ACT OF 1965, at 194-96 (1978) (discussing these attempts); GARY MAY, BENDING TOWARD Justice: The Voting Rights Act And the Transformation of American Democracy 204-10 (2013) (discussing the Voting Rights Act). See generally Solimine, Institutional, supra note 47 , at 784 n.76. 
process thereafter. ${ }^{143}$ Neither the majority nor the dissent in Shelby County made any specific qualitative or evaluative reference to the exclusive jurisdiction for preclearance litigation. ${ }^{144}$ If Congress revisits the preclearance process, it might find it difficult to again vest exclusive jurisdiction in the D.C. Circuit, as it would show a lack of confidence, however justified it might have been in 1965, in other federal judges throughout the country. ${ }^{145}$

143 Given the controversy over the constitutionality of the reauthorization of the preclearance provision in 2006, see, e.g., Richard L. Hasen, Congressional Power to Renew the Preclearance Provisions of the Voting Rights Act After Tennessee v. Lane, 66 OHIO ST. L.J. 177 (2005); Nathaniel Persily, The Promise and Pitfalls of the New Voting Rights Act, 117 YALE L.J. 174, 186-92 (2007), it is perhaps surprising that Congress did not include a special review provision to govern an expected constitutional challenge. Perhaps the assumption was that the three-judge district court convened to hear preclearance actions would naturally entertain such a challenge, as indeed it did in Nw. Austin Mun. Util. Dist. No. One v. Holder, 557 U.S. 193, 197 (2009) (noting how the court below addressed the constitutional question), aff'g on other grounds, 573 F. Supp. 2d 221 (D.D.C. 2008) (three-judge court). In contrast, the plaintiff in Shelby County did not request preclearance (or a bailout from preclearance requirements), but rather sought a declaratory judgment. 811 F. Supp. 2d 424, 427 (D.D.C. 2011), aff'd, 679 F.3d 848 (D.C. Cir. 2012), rev'd, 113 S. Ct. 2612 (2013). The same district judge held in related litigation that a three-judge district court under Section 5 need not be convened to hear a constitutional challenge when that remedy was sought. See Laroque v. Holder, 755 F. Supp. 2d 156, 165-66 (D.D.C. 2010), rev'd on other grounds, 650 F.3d 777 (D.C. Cir. 2011). For further discussion, see Solimine, Reapportionment, supra note 42, at 1138-39 \& n.151.

144 Nor did Justice Thomas, in his concurring opinion in Shelby County, 113 S. Ct. at 2631-32 (Thomas, J., concurring), or his dissenting opinion in NAMUNDO, 557 U.S. at 212-29 (Thomas, J., dissenting), both of which concluded that Congress lacked constitutional power in 2006 to renew $\S 5$ of the VRA.

145 The decision in Shelby County to strike down the current version of section 4 of the VRA has made moribund the preclearance provisions of Section 5. This in turn has reinvigorated interest in the heretofore relatively little used "bail-in" provisions of section 3 of the VRA. Adam Liptak \& Charlie Savage, U.S. Asks Court to Limit Texas on Ballot Rules, N.Y. TiMES, July 26, 2013, at A1 (discussing how the Obama Administration after Shelby County is attempting to use Section 3 regarding election law changes in Texas, previously governed by Section 5 preclearance). The bail-in provision, unlike the preclearance provision, first requires that a district court make findings that a state voting practice is unconstitutional, and then retaining jurisdiction to in effect preclear changes to such practices. 42 U.S.C. $\$ 1973 \mathrm{a}$ (c). Also unlike Section 5, the bail-in provision does not place venue in the DOJ or the federal courts in D.C., but rather before a three-judge district court in that state. The reason for the latter difference is not clear. Presumably it was based on the notion that local federal courts will be more familiar with the facts upon which a finding of unconstitutionality will be based. See Travis Crum, Note, The Voting Rights Act's Secret Weapon: Pocket Trigger Litigation and Dynamic Preclearance, 119 YALE L.J. 1992, 2008-09 (2010) ("In pocket trigger litigation, however, the local district court regains jurisdiction and can receive preclearance requests."). Should Congress revisit Sections 4 and 5 in the wake of Shelby County, the Section 3 model of vesting enforcement in local three-judge district courts, rather than in the District of Columbia, could provide a model. See Michael E. Solimine, Rethinking District of Columbia Venue in Voting Rights Preclearance Actions, 102 GEO. L.J. ONLINE 29, 40 (2014) (making this argument). 
In contrast to the VRA, the legislative history of the specialized review provisions, such as it is, says virtually nothing about why the District of Columbia is chosen. Perhaps it is due in part to strategic maneuvering by members of Congress, thinking that federal judges in the District simply know more about the legislative process and would be more (or depending on your point of view, less) likely to uphold the statute. Or, perhaps it is simply more convenient for Congress (and perhaps the lawyers expected to litigate such matters) to place jurisdiction in the District, especially given the provisions allowing for members of Congress to bring suit challenging the statutes. ${ }^{146}$ However, these are not especially sound reasons to require that such challenges, by members of Congress or anyone else, be brought in the District. The first contributes to the politicization of the federal judges in the District. The second elevates convenience to an unreasonably high virtue. The better course, if there has to be special review provisions at all, is to allow venue anywhere in the United States, just as it is with any other suit. ${ }^{147}$

\section{Trials by Three Judges, Expediting Decisions, and Supreme Court Docket Control}

In the abstract there is nothing wrong with setting up judicial procedures to require or encourage federal courts to expeditiously decide the constitutionality of federal statutes. Even when promptness is not directly necessary to the efficient operation of the law (consider, say, the Flag Protection Act), there is something to be said for questions over a statute that applies to the whole nation and which must be resolved as quickly as possible. That said, there can be too much of a good thing. There is considerable evidence that the expediting procedures for the litigation involving the 1974 Amendments to FECA, and at least in some instances for litigation under the BCRA, led to hurried proceedings at the lower court levels and an inadequate compilation of a record. ${ }^{148}$

146 For speculations along these lines, see Fraser et al., supra note 101, at 145-48; Solimine, Institutional, supra note 47 , at 773 .

147 Divesting the District of Columbia of exclusive jurisdiction over such cases might admittedly lead to an unseemly race to the courthouse by plaintiffs seeking a favorable forum. But that is true of other cases and is a necessary consequence and cost of geographically dispersed lower courts. The other putative benefits of the special review provisions would still accrue.

148 See, for example, on the Buckley $v$. Valeo litigation, Solimine, supra note 47 , at $775-76$ ("The Justices self-consciously took seriously the mandate to expedite their resolution of the case, and while it would be unfair to characterize Buckley as a rushed job (and Hasen does not), certain aspects of the opinion were not well thought out, and some of that 
A related problem is the convening of a three-judge district court to hold a hearing or trial, in which (among other things) evidence is taken, a record is assembled, and findings of fact and conclusions of law are entered, all normally the job of a single district judge. These are awkward tasks for most federal judges to undertake collectively. The awkwardness is compounded by the composition of the panel. At least one judge must be from the appellate court, so the panel consists of at least one judge who normally does not hold trials, and one or two trial judges whose work in other cases is reviewed by the same appellate judge. ${ }^{149}$ These administrative difficulties, among other things, contributed to the criticisms of the standing three-judge district court before its curtailment in $1976 .{ }^{150}$

These same critics argued that expediting mandates were unnecessary, since judges in the normal three-tier litigation process could, when necessary and upon request of the parties, expedite the process at the trial and appellate levels. ${ }^{151}$ It is true that modern (i.e., post1976) three-judge district litigation has a generally admirable record in rapidly litigating cases to final disposition (when there is an ap-

might be attributable to the unusual procedural posture of the case."); Panas, supra note 12, at 167-68 ("The Court's decision in Buckley $v$. Valeo is probably the most notorious example of expedited review occurring in an abstract factual context."). On McConnell $v$. FEC, 540 U.S. 93 (2003), see Solimine, Institutional, supra note 47, at 776-79 (discussing "the effect of the special review provisions in McConnell). On the other hand, many of the special review statutes seem to in effect authorize, and commonly lead to, facial constitutional attacks on statutes, as opposed to as-applied attacks. In theory, it would seem that this would mean less of a need to develop an extensive record at the trial level. No doubt, there are many exceptions to the generalization just made, with McConnell being a notable example. In any event, Professor Fallon's recent empirical study has considerably undermined the conventional wisdom that facial attacks on statutes are generally rare and unsuccessful in the Supreme Court. See generally Richard H. Fallon, Jr., Fact and Fiction About Facial Challenges, 99 CALIF. L. Rev. 915 (2011).

149 For discussion of these problems affecting three-judge district courts in general, see Solimine, Three-Judge District Court, supra note 42, at 116-18. For discussion on how these factors were arguably demonstrated at the trial level in McConnell, see Solimine, Institutional, supra note 47 , at $777-78$. For acknowledgment of the difficulties by judges sitting on three-judge district courts, see Common Cause v. Schmitt, 512 F. Supp. 489, 501-02 (D.D.C. 1980) (three-judge court), aff'd by an equally divided court, 455 U.S. 129 (1982). A countervailing consideration could be the possibility of a dissenting opinion on the three-judge court serving as a signal to the Supreme Court that the issues are contested and thus arguably more worthy of review. For discussion of that factor, drawing on studies of threejudge panels on the courts of appeals, see Frank B. Cross \& Emerson H. Tiller, Judicial Partisanship and Obedience to Legal Doctrine: Whistleblowing on the Federal Courts of Appeals, 107 Yale L.J. 2155, 2156 (1998); Matthew Spitzer \& Eric Talley, Left, Right, and Center: Strategic Information Acquisition and Diversity in Judicial Panels, 29 J. L. ECON. \& ORG. 638 (2011).

150 See supra notes 33-34 and accompanying text.

151 See supra note 35 and accompanying text. 
peal) to the Supreme Court. One recent study showed that "the Supreme Court disposes of most cases within about a year or less of the district court's final decision." ${ }^{152}$ But federal judges are capable of similarly swift decision-making under the three-tier process. Consider, again, the litigation that culminated in NFIB v. Sebelius. There, the federal district court (ten months after suit was filed) rendered a decision on January 31, 2011, and the court of appeals issued its decision on August 12 of that year. The Supreme Court promptly granted certiorari, ordered briefing and held oral arguments, and issued its decision on June 28, 2012. ${ }^{153}$ Granted, the individual mandate provision of the ACA was not due to go into effect until January 1, 2014, so the federal judges were not under extreme time pressures. Presumably the Supreme Court could have granted certiorari before judgment in the court of appeals ${ }^{154}$ or taken other steps to hasten the final disposition, if that had been necessary. But the timeline of NFIB $v$. Sebelius does suggest that expediting mandates found in statutes are usually not necessary. ${ }^{155}$

While expediting a particular case, direct review may place uncomfortable demands on docket management by the Supreme Court. During the heyday of the three-judge district court, when such appeals were inundating the Court's docket, some suggested that these appeals were forcing the hand of the Court. ${ }^{156}$ That is, the Court could not simply grant or deny certiorari; instead, it needed to ostensibly decide the case on the merits. ${ }^{157}$ The Court responded by decid-

152 Douglas, supra note 70 , at 459 . The conclusion is based on a review of the three-judge district court decisions reviewed by the Supreme Court from 2000 to 2009. Id. at 459-62.

153 For a listing of the decisions of the three courts, see supra note 5.

15428 U.S.C. § 1254(1) (2012) ("Cases in the courts of appeals may be reviewed by the Supreme Court by ... writ of certiorari granted upon the petition of any party to any civil or criminal case, before or after rendition of judgment or decree ....").

155 In this regard, consider the extensive litigation which challenged on constitutional and statutory grounds other aspects of the ACA. See Sheryl Gay Stolberg, A New Wave of Challenges to Health Law, N.Y. TimES, Dec. 3, 2013, at A1 (discussing some of these challenges). For example, after the Supreme Court's decision in Sebelius, there was a "flood of lawsuits" challenging, on First Amendment free exercise grounds and under the Religious Freedom Restoration Act, 42 U.S.C. $\$ \S 2000 \mathrm{bb}$ et seq., another provision (and its implementing regulations) of the ACA requiring employers to cover birth control in employee health plans. See Ethan Bronner, A Flood of Suits on the Coverage of Birth Control, N.Y. TIMES, Jan. 27, 2013, at A1. That litigation culminated in the Supreme Court's decision in Burwell v. Hobby Lobby Stores, Inc., 134 S. Ct. 2751 (2014), rendered only two years after Sebelius.

156 See Solimine, Three-Judge District Court, supra note 42, at 105 ("Another commentator has argued that direct review 'forc[es] the hand of the Supreme Court without benefit of prior appellate review.'”(citation omitted)).

157 In its most recent BCRA decision, the Court made the point strongly, observing that on a direct appeal, it had "'no discretion to refuse adjudication of the case on its merits." 
ing a significant percentage of those cases after full briefing and oral argument, and the rest by the awkward practice of a one-sentence summary affirmance, or occasionally a summary reversal. The latter were ostensibly on the merits, but came to be seen as possessing no precedential authority. Thus, it was near the functional equivalent of a denial of certiorari. ${ }^{158}$

To be sure, the statutory diminution of the three-judge district court in 1976 and the demise of most other direct appeals by $1988,{ }^{159}$ coupled with the Court's current shrunken docket, ${ }^{160}$ have lessened caseload pressures on the Court. In light of these developments, the demands of special review provisions with direct appeals are less of a burden on the Court. Granting that, the current direct appeals may still place cases before the Court at inopportune times, before it is ready to confront the issues. ${ }^{161}$ Consider here again the continuing stream of cases on direct appeal challenging various provisions of the BCRA. $^{162}$ In Citizens United, the Court majority reserved the question of whether its holding extended to political contributions by foreigners. $^{163}$ Some observers argued that any restriction of such spending by foreigners was at odds with the balance of the analysis of the majority. ${ }^{164}$ A challenge to the BCRA on that ground was promptly brought, and the lower court held that the BCRA could constitutionally limit spending by foreign contributors. ${ }^{165}$ Rather than fully exploring this potentially important issue, upon a direct appeal, the Court summarily affirmed. ${ }^{166}$ Thus, it utilized an old-fashioned safety-

McCutcheon v. FEC, 134 S. Ct. 1434, 1444 (2014) (quoting Hicks v. Miranda, 422 U.S. 332, $344(1975))$.

158 See Solimine, Three-Judge District Court, supra note 42, at 107-09 ("Still, the current manner of disposing of putatively mandatory appeals is not without its costs, which are similar to those attending the certiorari process.").

159 See supra notes 41-43 and accompanying text.

160 See generally Ryan J. Owens \& David A. Simon, Explaining the Supreme Court's Shrinking Dock$e t, 53$ WM. \& MARY L. REV. 1219 (2012).

161 Cf. David Fontana, Docket Control and the Success of Constitutional Courts, in Comparative Constitutional Law 624, 624 (Tom Ginsburg \& Rosalind Dixon eds., 2011) ("[C]ourts deciding constitutional cases benefit from having the power to set their agenda ....")

162 See supra note 52. At one point I referred to these cases as causing the Court "BCRAfatigue." Solimine, Institutional, supra note 42, at 779 .

163 Citizens United v. FEC, 558 U.S. 310, 362 (2009).

164 E.g., Richard L. Hasen, Citizens United and the Illusion of Coherence, 109 MiCH. L. REv. 581, 605-10 (2011) (discussing foreign spending).

165 Bluman v. FEC, 800 F. Supp. 2d 281, 283 (D.D.C. 2011) (three-judge court).

166132 S. Ct. 1087 (2012). Cf. Michael W. McConnell, Reconsidering Citizens United as a Press Clause Case, 123 Yale L.J. 412, 415-16 \& n.12 (2013) (stating that the Citizens United opinion is "overly long and unfocused. It seems to stretch for unnecessarily broad interpretations of free speech law .... Already the Court has been forced to cut back on one of the broader possible implications....") (citing the summary affirmance in Bluman). 
valve to avoid confronting a potentially difficult case. Absent the direct appeal, it may have waited until one or more courts of appeal decisions had been rendered before resolving the issue.

\section{Reconsidering the Constitutional Doubt Canon}

In their new treatise on statutory interpretation quoted at the beginning of this article, Justice Scalia and Professor Garner critically examine the venerable canon that federal statutes should, if necessary, be construed to avoid a reading that would render them unconstitutional. As they observe, this canon of statutory construction is premised on a "genuine assessment of probable meaning" on behalf of Congress. ${ }^{167}$ The legislature presumably only wishes to enact lawful statutes, so it should not be "presumed to be sailing close to the wind, so to speak-entering an area of questionable constitutionality without making that entrance utterly clear." ${ }^{168}$ Justice Scalia and Professor Garner continue that the presumption may not be justified today. Congress does sail close to the wind "all the time[,]" and the "questionable constitutionality" is evidenced and indeed acknowledged, they say, by Congress through the presence of special review provisions in statutes. ${ }^{169}$ Despite this criticism, Justice Scalia and Professor Garner ultimately conclude that the constitutional doubt canon should continue to be supported. ${ }^{170}$

Despite their ultimate reticence, a plausible inference of Justice Scalia and Professor Garner's view of the special review provisions is that the canon should not hold, or perhaps should even be reversed, when a statute under constitutional attack contains such a provision. ${ }^{171}$ A full discussion of the considerable debate over the canon is beyond the scope of this Article. ${ }^{172}$ What is worth addressing here is

167 SCALIA \& GARNER, supra note 1 , at 248.

$168 I d$.

169 Id.

$170 I d$. at 249. They argue that " [a] more plausible basis for the rule is that it represents judicial policy" to minimize "judicial conflicts with the legislature." Id.

171 In an earlier reference to these provisions, Justice Scalia stated that "if Congress is going to take the attitude that it will do anything it can get away with and let the Supreme Court worry about the Constitution,' then 'perhaps th[e] presumption [that acts of Congress are constitutional] is unwarranted." Devins, supra note 92, at 280 n.69 (quoting Stuart Taylor, Jr., The Tipping Point, 32 NAT'L J. 1810, 1811 (2000) available at http://nationaljournal.com/magazine/judiciary-the-tipping-point-20000610).

172 For articles discussing the debate over the canon, see, e.g., Gillian E. Metzger \& Trevor W. Morrison, The Presumption of Constitutionality and the Individual Mandate, 81 FORDHAM L. REV. 1715 (2013); John Copeland Nagle, Deleware \& Hudson Revisited, 72 Notre Dame L. REV. 1495 (1997); Frederick Schauer, Ashwander Revisited, 1995 SuP. CT. REV. 71; Adrian Vermeule, Saving Constructions, 85 GEO. L.J. 1945 (1997); Ernest A. Young, Constitutional 
whether Scalia and Garner are correct to identify the special review provisions as signals of the alleged constitutional questionability of federal statutes.

In my view, Justice Scalia and Professor Garner give too much weight to the presence of special review provisions in particular statutes. It is true, as they point out, that many of the statutes with such provisions have been later held to be unconstitutional, in whole or in part, by the Supreme Court. ${ }^{173}$ But the Court has not held all such statutes to be unconstitutional, ${ }^{174}$ and others have been resolved by the Supreme Court on other grounds. ${ }^{175}$ While the number of such statutes is not trivial, or most do not deal with trivial matters, ${ }^{176}$ the sample size is relatively small to draw definitive conclusions about congressional signaling. Moreover, the rate of unconstitutionality of such statutes cannot be said to be strikingly different from that of all considerations of the constitutionality of federal statutes by the Court. Recent studies indicate that throughout American history, the Court has considered the constitutionality of a federal statute about 792 times, and struck down the statute 173 times, or about $22 \%$ of the time. ${ }^{177}$ This is not a robust rate of unconstitutionality, showing Con-

Avoidance, Resistance Norms, and the Preservation of Judicial Review, 78 Tex. L. Rev. 1549 (2000); see also Abbe R. Gluck \& Lisa Schultz Bressman, Statutory Interpretation from the Inside-An Empirical Study of Congressional Drafting, Delegation, and the Canons: Part I, 65 STAN. L. REV. 901, 947-48 (2013) (discussing survey of congressional staffers tasked with drafting legislation which found that most were unaware of the constitutional avoidance canon, but most also anticipated that the courts would rule on the constitutionality of statutes). For an analysis of Scalia and Garner's treatment of the constitutional avoidance canon in their treatise, see William N. Eskridge, Jr., The New Textualism and Normative Canons, 113 Colum. L. Rev. 531, 543, 569 (2013) (reviewing ANTONIN SCALIA \& BRYAN A. Garner, ReAding LaW: The InTERPRetation Of Legal TeXts (2012)). None of these sources specifically address what interpretive weight, if any, courts should give to the presence or absence of special review provisions.

173 SCALIA \& GARNER, supra note 1, at 248-49 nn. 7-9 (giving examples of statutes declared unconstitutional). They do not cite instances of such statutes being upheld. See id.

174 See, e.g., the initial adjudication of the BCRA, supra note 51, and the adjudications of the Cable Television Consumer Protection and Decency Act, supra note 56, of the census reform legislation, supra note 61, and of the REAL ID Act, supra note 63.

175 In several instances the Court has declined to review lower court decisions upholding statutes with special review provisions. For examples, see supra notes $62,65, \& 66$. In the litigation over the census reform legislation, the majority of the Court (perhaps ironically) employed the constitutional doubt canon to resolve the case on non-constitutional grounds. See supra note 6.

176 Some might include the Saxbe Fix statutes in the category of trivia, but the BCRA and many of the other statutes clearly do not fall into that category.

177 Jenna Becker Kane \& David Adamany, Judicial Activism Once Again Reconsidered, 21 TABLE 3 (2013) (presenting data from Marshall through Roberts Courts) (paper presented at annual meeting of the Midwest Political Science Association, April 11-14, 2013, Chicago, Ill.) (on file with author). 
gress sailing close to the wind. But the rate is much higher for recent decades. In the Warren through Roberts Courts, the numbers and rate are 247,104 , and $42 \%$, respectively. ${ }^{178}$ The rate of unconstitutionality is higher than that for the recent statutes with the special review provisions, and the difference is accentuated by the fact that the overall figures include the adjudications involving the latter statues. Nonetheless, it cannot be said the finding of unconstitutionality is a rare event, with the latter statutes being a conspicuous exception.

The overall context of the passage of statutes with special review provisions also undercuts Justice Scalia and Professor Garner's position. As I earlier argued, ${ }^{179}$ a richer and more realistic appraisal of the reasons Congress passes these provisions suggests that it is not merely indicative of Congress mindlessly sailing close to the wind. Instead, a confluence of rational and practical reasons, similar to that which attends the passage of most legislation, explains why Congress included the special review provisions. I do not find these reasons to be especially convincing as a matter of policy, and I ultimately concluded that their possibly negative effects on decision-making by lower federal courts and the Supreme Court ${ }^{180}$ suggest that Congress should not utilize these provisions. Nonetheless, these criticisms do not support the strong version of the argument that the special review provisions are unambiguous signals of probable unconstitutionality to the federal courts. Rather, the rationales and effects of the provisions are on the whole ambiguous, so federal courts should be hesitant to draw interpretive conclusions from their presence or absence in particular statutes.

\section{Summing Up}

The conventional critique of the special review provisions contends that they are examples of Congress abdicating its responsibility to take seriously the constitutional validity of statutes it passes. This critique is incomplete. While it is true that Congress in recent decades has, by traditional measures, devoted less attention to the constitutional status of statutes it considers and may enact, it does not follow that the special review provisions are especially problematic examples of that tendency. Congressional motivation can be multifarious when it comes to any statute, and in my view the legislative record on these provisions is no different. Congressional abdication

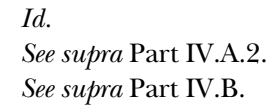


of constitutional responsibility may play a part, but the provisions can also be conceptualized as Congress taking those responsibilities seriously for that particular statute, by inviting the federal courts (and often the most prestigious lower court) to rule quickly on the constitutional issues.

Despite this somewhat more benign view of the legislative purpose of the special review provisions, I still conclude that they are not sound additions to the institutional structure of federal courts. There are several aspects of their effect on federal court decision-making that is troublesome. These include the lack of percolation, the unnecessary directives for rapid decisions, and the unnecessary exclusive venue often placed in the federal court for the District of Columbia. These negative effects on the judicial decision-making process outweigh the modest, possibly positive impact the provisions have on a dialogue between Congress and the federal courts. The normal federal court process to determine the constitutionality of federal statutes is up to the task, and the special review provisions are unnecessary.

\section{CONCLUSION}

Since 1803 the federal courts have possessed the authority to consider the constitutionality of federal statutes. For most years since 1891, that sort of litigation, and most other litigation as well, has taken place within the now familiar three-tier process, of a trial court decision by a single judge, followed by a right of appeal to a three-judge panel on a regional court of appeals (sometimes augmented by en banc review), followed (since 1925) by discretionary review in the $\mathrm{Su}$ preme Court. Congress experimented with a different approach from 1937 to 1976, with three-judge district courts being convened to hear constitutional challenges to a federal statute, followed by a direct appeal to the Supreme Court. After critics, including Justices on the Court itself, pointed to administrative burdens and the arguable lack of reason for this different process, Congress repealed the experiment.

However, since the abandonment of the standing (if temporarily convened) three-judge district court, Congress has seen fit to place similar provisions in a number of particular federal statutes. They are similar but not identical to the prior experiment, and to each other, but the new provisions typically also mandate that the suit be brought in the District Court for the District of Columbia, that members of Congress can bring or intervene in such suits, and that federal judges should expeditiously decide the cases. The ostensible reasons for 
these provisions are doubts about the constitutionality of the statutes, and a perceived need to quickly decide such cases and resolve constitutional questions about a statute. These are the new specialized (albeit temporarily-convened) federal constitutional courts.

There is nothing sacred about our current federal judicial architecture, but any significant deviation should, in my view, be justified. There are not convincing justifications for these specialized constitutional courts. I do not take the view of some critics that they are unqualified evidence of the constitutional weakness of a particular statute, or of abdication by Congress of its responsibility to seriously consider the constitutionality of legislation it enacts. Other, more mundane reasons may account for the proliferation of these provisions. However, I conclude that the provisions are on balance unnecessary and in some ways may be harmful to the consideration of these important constitutional issues, by, among other things, potentially depriving the Supreme Court of the percolation of views by more than one lower federal court.

The best path, then, would be for Congress not to further enact these provisions. Should it insist on doing so, however, Congress should draft them in different ways. It should replicate more closely the experiment from 1937 to 1976 which, for all of its infirmities, cannot be said to have been a disaster. Members of Congress can do so by placing these provisions in the bills originally introduced, rather than adding them, as they often are, in last-minute final votes on the floor of Congress. This would serve the salutary purposes of alerting the rest of the Congress that there may indeed be special constitutional issues with that particular statute, and permitting discussion of the necessity of the special review provisions themselves. ${ }^{181}$ Likewise, there is no need to place exclusive jurisdiction in the District of Columbia or of formally mandating expeditious treatment. The former inappropriately elevates the importance of federal courts in the District, and the latter is unnecessary, as experience shows that federal judges can, when requested and when necessary, rapidly decide cases. These would be sounder attributes of specialized federal constitutional courts.

181 Cf. Hanah Metchis Volokh, Constitutional Authority Statements in Congress, 65 FLA. L. REV. 173, 214-15 (2013) (arguing that constitutional authority statements should be required at earlier and multiple times in the legislative process, to have desired effect on congressional deliberation). 